
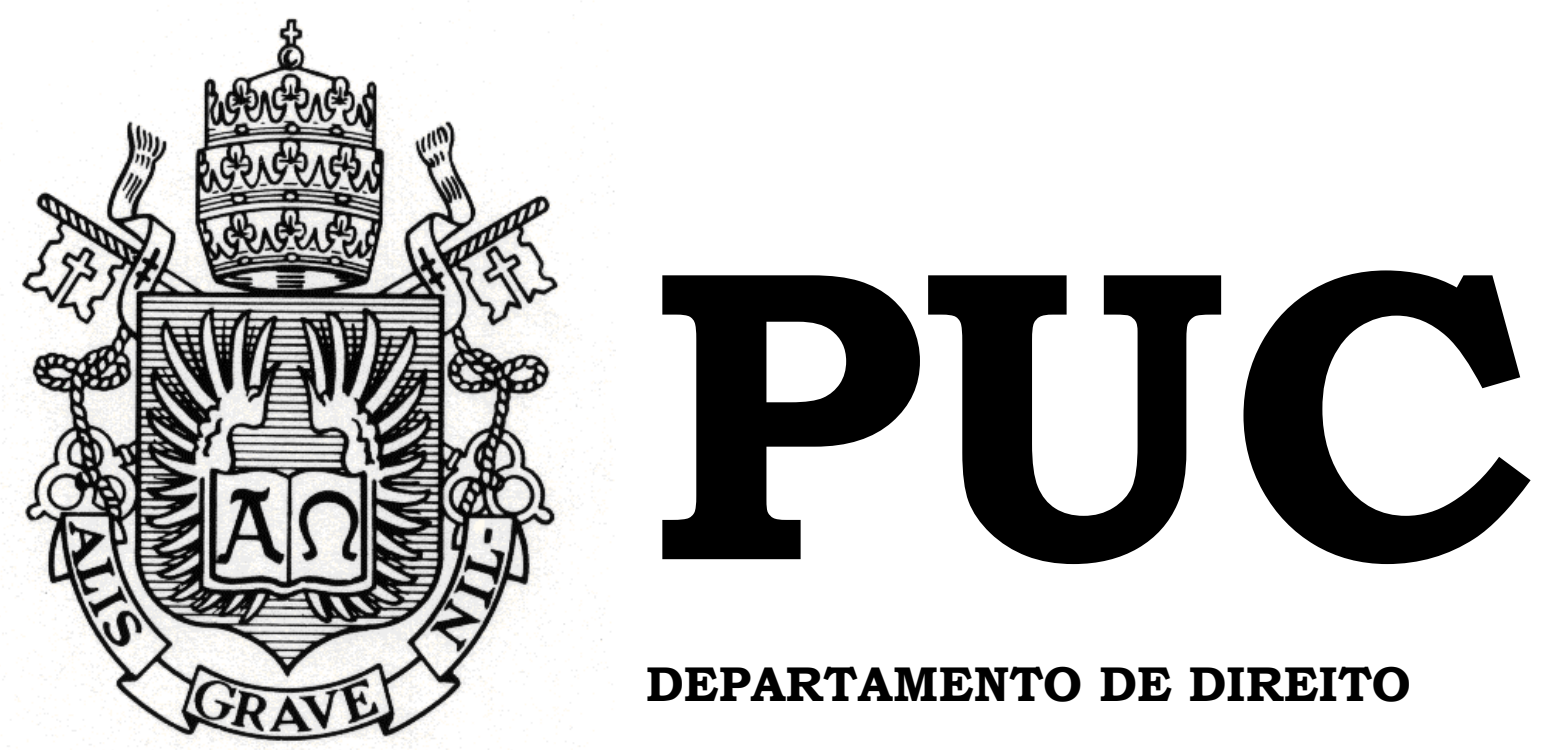

DEPARTAMENTO DE DIREITO

\title{
EXECUÇÃO DE CONTRATO DE CÂMBIO DE EXPORTAÇÃO
}

por

LUIZ FELIPE SALGUEIRO NOVAES

ORIENTADOR: Marcello Oliveira

2009.1

PONTIFÍCIA UNIVERSIDADE CATÓLICA DO RIO DE JANEIRO

RUA MARQUÊS DE SÃO VICENTE, 225 - CEP 22453-900

RIO DE JANEIRO - BRASIL 


\title{
EXECUÇÃO DE CONTRATO DE CÂMBIO DE EXPORTAÇÃO
}

\author{
por \\ LUIZ FELIPE SALGUEIRO NOVAES
}

Monografia apresentada ao Departamento de Direito da Pontificia Universidade Católica do Rio de Janeiro (PUC-Rio) para a obtenção do Título de Bacharel em Direito.

Orientador: Marcello Oliveira 


\section{DEDICATÓRIA}

Sabedor da contribuição que cada pessoa teve para o sucesso da minha trajetória, mas sem medo ou receio de estar sendo injusto com quem quer que seja, dedico este trabalho àquela que sempre acompanhou de perto todos os momentos do caminho percorrido para chegar até aqui, essa dedicatória é exclusiva à minha mãe, motivo de orgulho e em quem me espelho. 
NOVAES, Luiz Felipe. Execução de Contrato de Câmbio de Exportação. Rio de Janeiro, 2009. 71 p. Monografia de final de curso - Departamento de Direito, Pontifícia Universidade Católica do Rio de Janeiro.

O presente trabalho tem como objeto o estudo da execução judicial do contrato de câmbio de exportação inadimplido pelo exportador cliente da instituição financeira, a fim de demonstrar o caminho a ser seguido em Juízo pela instituição credora para fins de ressarcimento dos prejuízos por ela porventura sofridos em razão do inadimplemento contratual daquele, bem como para recuperação do eventual adiantamento concedido pelo banco sobre o preço das divisas negociadas neste contrato.

Para tanto, estabeleceu-se determinadas bases conceituais concernentes ao mercado, às operações e ao contrato de câmbio em si, definindo sua natureza jurídica. Em seguida, foi feita a análise das conseqüências jurídicas decorrentes do inadimplemento do referido contrato, bem como da ação de execução judicial do contrato não cumprido por devedor solvente. Por fim, as atenções se voltaram para as nuances da recuperação do crédito oriundo do contrato de câmbio de exportação nas hipóteses de falência ou recuperação judicial do exportador devedor.

Palavras-chave: Contrato de câmbio; exportação. natureza jurídica; adiantamentos sobre os contratos de câmbio (ACC); inadimplemento; execução judicial; falência; pedido de restituição; recuperação judicial. 


\section{SUMÁRIO}

INTRODUÇÃO .........................................................................................................5

Capítulo I - NOÇÕES GERAIS ......................................................................... 8

1.1 CONCEITOS BÁSICOS - MERCADO, OPERAÇÕES E CONTRATO

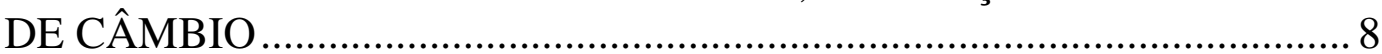

1.1.1 O Contrato de Câmbio de Exportação..................................................... 10

1.2 NATUREZA JURÍDICA DO CONTRATO DE CÂMBIO .................... 14

Capítulo II - O INADIMPLEMENTO DO CONTRATO DE CÂMBIO

DE EXPORTAÇÃO ................................................................................................ 23

2.1 CONSEQÜÊNCIAS JURÍDICAS DA INADIMPLÊNCIA................... 23

2.2 EXECUÇÃO JUDICIAL DO CONTRATO DE CÂMBIO CONTRA

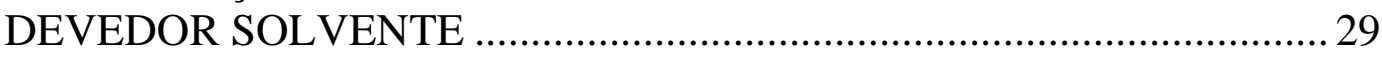

2.2.1 Contrato de Câmbio como Título Executivo Extrajudicial................. 30

2.2.2 Protesto do Contrato de Câmbio............................................................ 33

2.2.3 Procedimento para Execução do Contrato de Câmbio .......................... 37

Capítulo III - A RECUPERAÇÃO DO CRÉDITO DO CONTRATO DE CÂMBIO DE EXPORTAÇÃO QUANDO DA FALÊNCIA OU RECUPERAÇÃO JUDICIAL DO DEVEDOR-EXPORTADOR......... 44

3.1 BREVE CONTEXTO DA NORMA ATINENTE À MATÉRIA.......... 44

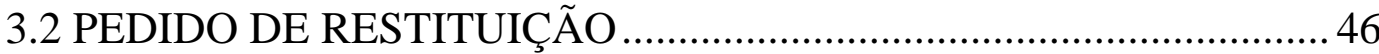

3.3 RECUPERAÇÃO DO CRÉDITO CONTRA DEVEDOR-

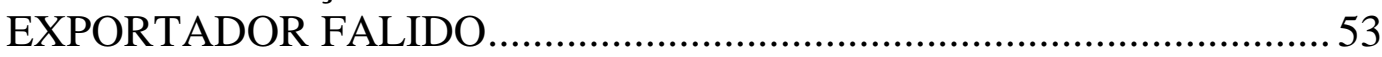

3.4 SUJEIÇÃO DO CRÉDITO ORIUNDO DE ACC AOS EFEITOS DA RECUPERAÇÃO JUDICIAL DO DEVEDOR-EXPORTADOR...............59

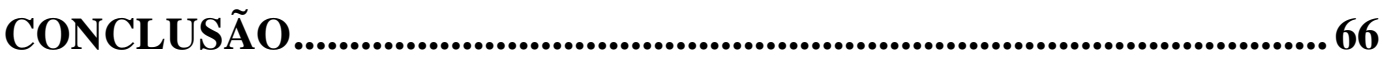

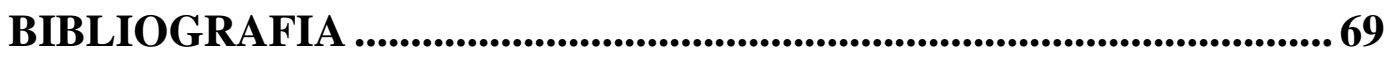




\section{INTRODUÇÃO}

O tema desta monografia envolve o instrumento especial firmado entre o exportador vendedor de divisas e a instituição financeira compradora das mesmas, de cunho obrigatório por força de lei, que é o Contrato de Câmbio de Exportação.

Salienta-se que o estímulo às exportações, seja na atual política econômica caracterizada pela inserção no processo de globalização seja no modelo de substituição das importações adotado até o fim dos anos 80, sempre fora buscado como um dos mais importantes instrumentos de fortalecimento da economia nacional.

Os negócios de câmbio têm como base o comércio internacional e os movimentos de capitais e moedas internacionais, consistindo basicamente na troca (conversão) da moeda de um país pela do outro, sendo necessários em função de exportações, importações e operações financeiras. Trata-se, portanto, de negócio de alta relevância para as transações e fluxos de pagamentos internacionais, de forma que atraiu intensa regulamentação estatal, que se interessou pela matéria como forma de controle da economia e da balança de pagamentos do Brasil, a qual reflete o resultado do somatório dessas operações cambias.

A necessidade do mercado de câmbio decorre, fundamentalmente, da internacionalidade do comércio em confronto com o nacionalismo das moedas. $\mathrm{O}$ fato de não se aceitar moedas estrangeiras em pagamento das exportações, nem a moeda nacional em pagamento das importações, constitui a base de um mercado onde são compradas e vendidas as moedas dos diversos países.

Se houvesse apenas uma moeda no mundo, não existiriam os problemas cambiais e esta monografia perderia seu objeto. Entretanto, considerando que qualquer concretização de idéias no sentido de se instituir uma moeda única mundial nos parece ser algo bastante distante, senão 
utópico, temos a convicção de que referido tema permanecerá em voga por ainda muitas gerações.

Por oportuno, adianta-se que o presente trabalho voltou sua atenção para a execução judicial do contrato de câmbio de exportação inadimplido pelo exportador cliente da instituição financeira.

Isso porque, acredita-se que as discussões que envolvem o trâmite a ser percorrido em Juízo pelo credor do contrato de câmbio de exportação, patrocinam a busca pelo interesse nacional de estímulo às exportações na medida em que garantem às instituições credoras neste contrato, meios eficientes para ressarcimento dos prejuízos causados pelo inadimplemento do cliente exportador, bem como para recuperação do eventual adiantamento concedido sobre o preço das divisas negociadas.

A idéia, portanto, é que os bancos tenham a confiança de que, quando do inadimplemento do contrato pelo exportador, serão grandes as chances de recuperação do prejuízo sofrido ou do valor adiantado.

O presente trabalho está dividido em três capítulos, a fim de se obter uma melhor didática para exposição do tema. Procurando desbastar as arestas iniciais, o primeiro capítulo estabelece as bases conceituais concernentes ao mercado, às operações e ao contrato de câmbio em si, além de analisar a sua natureza jurídica para fazer aplicar sobre o instituto as disposições cabíveis e estudar o assunto à luz destas. Ademais a abordagem sobre o adiantamento de contrato de câmbio (ACC) por meio do qual os bancos financiam o capital de giro das empresas exportadoras sob a forma de antecipação dos recursos a serem recebidos do comprador estrangeiro, será exposta neste capítulo.

O segundo capítulo, por sua vez, busca analisar as conseqüências jurídicas do inadimplemento do contrato de câmbio de exportação pelo exportador, e, conseqüentemente, estudar as nuances da ação de execução judicial do contrato não cumprido por devedor solvente. Essa execução consiste no meio que deve ser utilizado pelo banco para fins de haver do 
inadimplente os prejuízos por ele sofridos além do eventual adiantamento concedido sobre o preço do contrato.

Por fim, o terceiro capítulo é o ponto central deste trabalho e visa evidenciar os aspectos da recuperação do crédito oriundo do contrato de câmbio de exportação nas hipóteses de falência ou recuperação judicial do exportador devedor.

A abordagem que será feia no último Capítulo envolve a adequada intelecção das leis que regulam a matéria ali exposta, ressaltando-se o verdadeiro significado da norma e a harmonia do seu texto com sua finalidade precípua.

Frisa-se que o quarto capítulo não visa defender uma tese, seja ela contra ou favor dos eventuais privilégios concebidos pelo ordenamento aos credores do contrato de câmbio de exportação quando da falência ou recuperação judicial do exportador, mas sim expor os interesses e objetivos visados pela norma, com o fim de se buscar uma compreensão adequada quanto ao tema em questão. 


\section{Capítulo I - NOÇÕES GERAIS}

\subsection{CONCEITOS BÁSICOS - MERCADO, OPERAÇÕES E CONTRATO DE CÂMBIO}

Antes de adentrar no estudo acerca da execução do contrato de câmbio de exportação, é fundamental estabelecer algumas bases conceituais para o trabalho, concernentes ao mercado, às operações e ao contrato de câmbio em si. Essa breve exposição teórica contribuirá para compreender como este negócio jurídico é estruturado.

Em linhas gerais, o mercado de câmbio, que juntamente com o mercado monetário, de crédito e de capitais, compõe o sistema financeiro, é aquele que envolve a negociação de moedas estrangeiras e os agentes econômicos interessados em movimentar essas moedas. Esses agentes dividem sua participação neste mercado entre aqueles que produzem divisas, contribuindo para o ingresso de moeda estrangeira no país, e os que cedem divisas, remetendo moeda estrangeira ao exterior, sendo os negócios de câmbio tradicionais voltados à viabilização desses fluxos internacionais de pagamentos.

De acordo com a legislação brasileira, as operações de câmbio não podem ser praticadas livremente e devem ser conduzidas através de um estabelecimento bancário autorizado a operar em câmbio e sob as condições estabelecidas pelo Banco Central do Brasil - BACEN ${ }^{1}$. Esses bancos autorizados a operar no mercado de câmbio caracterizam-se como órgãos de pagamentos internacionais, utilizando-se de suas agências e correspondentes no exterior.

Temos, portanto, que o mercado de câmbio no Brasil não é, sob determinado prisma a seguir esclarecido, de livre acesso, estando sujeito ao controle governamental em toda sua extensão ${ }^{2}$. De um lado, a atuação

\footnotetext{
${ }^{1}$ Neste trabalho o termo Banco Central do Brasil será substituído por BACEN.

${ }^{2}$ Ressalta-se que o Conselho Monetário Nacional, por intermédio da Resolução n 3.265, de 2005, implantou nova filosofia cambial no País, com ampla liberdade para compra e venda de moeda
} 
profissional na área de câmbio, requer prévia autorização e forma especial de empresa, estando a atividade totalmente ordenada através de uma série de normas legais e regulamentares. De outro lado, as pessoas em geral interessadas ou necessitadas de participar deste mercado, são obrigadas a recorrer ao sistema institucional de câmbio para fazerem as operações de compra ou de venda de moeda estrangeira.

O objetivo desse controle de movimentação de divisas realizado pelo BACEN é de evitar a evasão das mesmas, ou seja, que a moeda permaneça no exterior em nome de terceiros, em detrimento do Brasil. Pela nossa legislação, o uso de moedas estrangeiras nas transações internas é proibido ${ }^{3}$, assim como seu depósito em contas correntes juntos aos bancos do País, de forma que, os pagamentos e recebimentos relativos às operações cambiais são efetuados entre estabelecimentos bancários, sem que ocorra transferência física da moeda objeto da transação.

O contrato de câmbio, disciplinado pela Lei 4.595, de 30/09/64, e consolidado no Regulamento do Mercado de Câmbio e Capitais Internacionais - RMCCI, divulgado pela Circular do BACEN n 3.280, de 09/05/05 e suas inúmeras alterações posteriores, visa, na realidade, a prestação de um serviço pelo banco ao seu cliente, tendo por objetivo principal a compra e venda de moeda estrangeira.

Define-se o contrato de câmbio como sendo o instrumento firmado entre as partes envolvidas na compra e venda de moedas estrangeiras, do qual constam as características completas das operações de câmbio e as condições sob as quais as mesmas se realizarão. Trata-se, portanto, de um negócio jurídico através do qual se formalizam as transações em moedas

estrangeira no mercado de câmbio, sem necessidade de autorizações específicas do Banco Central do Brasil, desde que observados os princípios da legalidade e da fundamentação econômica, bem como as responsabilidades definidas na respectiva documentação.

${ }^{3}$ BRASIL. Lei $n$ 10.406, de 10 jan 2002. Código Civil. Arts. 315 c/c 318, in verbis:

“Art. 315. As dívidas em dinheiro deverão ser pagas no vencimento, em moeda corrente e pelo valor nominal, salvo o disposto nos artigos subseqüentes.

(...)

Art. 318. São nulas as convenções de pagamento em ouro ou em moeda estrangeira, bem como para compensar a diferença entre o valor desta e o da moeda nacional, excetuados os casos previstos na legislação especial." 
estrangeiras, ou seja, é um acordo entre as partes contratantes para entrega de certa quantidade em moeda estrangeira a um certo preço e dentro de determinadas condições.

\subsubsection{O Contrato de Câmbio de Exportação}

O contrato de câmbio de exportação, espécie do gênero contrato de câmbio e que é o foco do presente trabalho, é celebrado entre exportadores e instituições financeiras e é de cunho obrigatório para o exportador no Brasil. Esse contrato está sujeito a intensa fiscalização federal, na qual são traçadas normas rígidas atinentes ao controle das divisas de exportação, de forma que a própria formalização das operações de câmbio em si (contratação, alteração, cancelamento ou baixa) é feita com a utilização, exclusivamente, de formulários de contratos cujos modelos são instituídos pelo BACEN ${ }^{4}$.

Nesse sentido, verifica-se que é muito pequena a margem de manifestação de vontade das partes na celebração de um contrato de câmbio, cabendo-lhes, quase que tão somente, optar por um dos esquemas já pré-estabelecidos, objeto de formulários próprios, conforme acima mencionado 5 .

O Contrato de Câmbio deve conter os seguintes dados:

- nome do banco autorizado a contratar o câmbio;

- nome do exportador;

- valor da operação;

\footnotetext{
${ }^{4}$ Ressalta-se que a Lei ${ }^{\circ} 11.371 / 06$ dispensou o uso, nas operações de até US\$ 3 mil, do formulário de contrato de câmbio na forma definida pelo Banco Central, prevista na legislação brasileira para todas as operações de câmbio. Essa medida teve como objetivo reduzir custos para pequenas transferências para o exterior, em especial aquelas realizadas no interesse de pessoas físicas residentes no Brasil e no exterior. Em consonância, a Resolução ${ }^{\circ} 3.568$, de 2008, dispensou a apresentação da documentação referente aos negócios jurídicos subjacentes às operações de câmbio de até US\$ 3 mil, mantida a exigência de identificação dos clientes.

${ }^{5}$ Nas exportações com prazo não superior a 180 dias, contado da data do embarque das mercadorias, o Fechamento do Câmbio com um banco autorizado e escolhido pelo exportador é formalizado com o preenchimento do formulário BACEN - TIPO 01. O formulário deve ser preenchido e registrado no Sistema de Informações Banco Central (SISBACEN), que monitora as operações cambiais.
} 
- taxa de câmbio negociada;

- prazo para liquidação;

- nome do corretor de câmbio, se houver;

- comissão do corretor de câmbio;

- nome do importador;

- dados bancários do exportador;

- condições de financiamento, etc.

Nessa modalidade, o contrato de compra de câmbio é um ato bilateral e oneroso pelo qual o exportador vende ao banco divisas estrangeiras, cuja entrega poderá ser à vista ou a prazo. A venda de divisas subordina-se à prévia existência de um comprador no exterior para as mercadorias que serão exportadas e cuja relação jurídica com o exportador brasileiro é formalizada pela existência de um contrato de compra e venda mercantil.

A contratação total ou parcial do câmbio entre exportador e instituição financeira autorizada a operar neste mercado, poderá ocorrer prévia ou posteriormente ao embarque da mercadoria. A definição do momento mais apropriado para a celebração desse contrato depende da necessidade de recursos financeiros para a elaboração do produto a ser exportado, da taxa de juros nominal vigente e da expectativa de alterações na taxa de câmbio, entre a data escolhida para a contratação e a data da liquidação do contrato de câmbio.

A sistemática nesses contratos de câmbio é que o exportador, tendo contratado, no âmbito de sua atividade, uma compra e venda internacional, procura um banco para oferecer-lhe à venda as divisas provenientes dessa transação internacional. $\mathrm{O}$ exportador faz esse contato direta ou indiretamente, na extensão em que se utiliza da figura de um corretor ou não, e quando efetivar a exportação. O banco, para fins de decidir se aceitará ou não comprar essas divisas, verifica a consistência dos documentos de exportação que o exportador lhe apresenta, assim como leva em consideração a credibilidade do cliente. 
Optando por celebrar o contrato de câmbio de exportação, o banco adquire a moeda estrangeira que virá a ser recebida pelo exportador no futuro, de forma que, caracteriza-se como objeto deste contrato, a compra e venda da moeda procedente da venda internacional. $\mathrm{O}$ vendedor (cliente) ainda não tem a mercadoria (moeda estrangeira), mas obriga-se a entregá-la no futuro.

Importante frisar que o negócio anterior de compra e venda internacional e a consequiente exportação da mercadoria são estranhos ao banco, sendo apenas a justificativa necessária para a compra e venda da moeda, caso contrário, se estaria fazendo um negócio de mútuo interno, com taxa de pagamento em dólares, o que é terminantemente proibido pela legislação brasileira ${ }^{6}$.

Diante do exposto, podemos resumir o funcionamento da operação da seguinte forma:

(i) quando da exportação, o exportador brasileiro celebra (ou, na linguagem bancária, fecha) um contrato de câmbio com uma instituição financeira. Pela celebração desse contrato, o banco compra a moeda estrangeira a que o exportador brasileiro terá direito quando o preço da mercadoria exportada for regularmente pago pelo importador estrangeiro;

(ii) Recebendo a moeda estrangeira paga pelo importador estrangeiro, o banco obriga-se a repassar ao exportador brasileiro o valor em moeda brasileira correspondente à moeda estrangeira recebida;

(iii) Assim, tendo cada um dos agentes envolvidos funções próprias, fecha-se o ciclo no qual o exportador brasileiro remete a mercadoria ao importador estrangeiro que, recebendo-a, vai a um banco de seu país para transferir o dinheiro correspondente ao pagamento do preço das mesmas ao banco brasileiro que, por sua vez, ao receber estas moedas estrangeiras, faz o cálculo do valor correspondente em moeda nacional e credita na conta do exportador brasileiro.

\footnotetext{
${ }^{6}$ Vide nota 3.
} 
Cumpre ressaltar, que o cumprimento do contrato de câmbio independe dos resultados do negócio jurídico subjacente celebrado entre exportador e importador, pois, ao vender a moeda estrangeira ao banco através do contrato de câmbio, o exportador assumiu a obrigação de fazê-la entrar no País, sendo o risco do negócio, nesse aspecto, exclusivamente dele. Isso se deve ao fato de que a instituição financeira que fechou o contrato de câmbio com o exportador não participa desta operação de compra e venda internacional de mercadorias, quer quanto à sua avaliação, quer quanto à análise do risco existente, nada tendo a ver com o insucesso da exportação.

Dessa forma, só teremos o contrato de câmbio liquidado, com o crédito da moeda estrangeira na conta do banco brasileiro no exterior, isto é, com a efetiva transferência de divisas, sendo que a entrega dos documentos de exportação pelo exportador não o libera da responsabilidade principal objeto do contrato de câmbio, que é a efetiva entrega da moeda estrangeira. Aliás, essa obrigatoriedade é estampada no verso do próprio modelo de instrumento de contrato de câmbio de exportação constante dos formulários do BACEN, não deixando dúvidas de que a responsabilidade do vendedor de câmbio (exportador) se estende até o recebimento das divisas pelo comprador (instituição financeira).

Pela própria natureza jurídica do contrato de câmbio abaixo analisada, não há como se defender que esse tipo de contrato seja subordinado ao bom ou mau cumprimento do compra e venda mercantil internacional pelo importador estrangeiro, negócio jurídico totalmente distinto do contrato de câmbio. Logo, a responsabilidade do exportador perante o banco pela venda da moeda estrangeira realizada, independe do adimplemento do negócio que anteriormente realizara com o importador estrangeiro, de forma que tirar essa característica do contrato de câmbio é desfigurá-lo como se verá a seguir. 


\subsection{NATUREZA JURÍDICA DO CONTRATO DE CÂMBIO}

Considerando que a opinião mais acatada e difundida entre os doutrinadores é a de que o contrato de câmbio é uma modalidade do contrato de compra e venda, opinião tradicional que já era consagrada em nosso Código Comercial, no antigo art. 191, $2^{\text {a }}$ alínea $^{7}$ que incluía a moeda metálica e o papel-moeda como objetos da compra e venda mercantil, pretende-se investigar neste tópico a natureza jurídica desse contrato tão usualmente praticado pelas instituições bancárias.

Como bem ressaltou Fernando Cavalcanti sobre esse ponto específico:

O 'CONTRATO DE COMPRA E VENDA DE CAMBIAIS E MOEDAS ESTRANGEIRAS', denominação que lhe dá o Decreto-Lei 9.025, de 27/2/44, e a Lei 4.595, de 31/12/64 - art. 19, abrangente do CONTRATO DE CÂMBIO DE EXPORTAÇÃO, é, como o próprio nome já diz, uma COMPRA e VENDA, em regra celebrada a termo, em que uma instituição financeira, autorizada a operar em câmbio, adquire as divisas do exportador, a serem entregues no vencimento, ajustado contratualmente (art. 197, Código Comercial) e se obriga a pagar-lhe o valor correspondente em moeda nacional ${ }^{8}$

Com isso, pretendemos, inicialmente, repassar alguns tópicos do contrato de compra e venda que tenham a ver com a natureza jurídica do contrato de câmbio de exportação.

Pois bem, pelo contrato de compra e venda, uma das partes se obriga a transferir a propriedade de uma coisa à outra, recebendo em contraprestação determinada soma em dinheiro ${ }^{9}$, tratando-se, pois, de um

\footnotetext{
${ }^{7}$ Art. 191 - O contrato de compra e venda mercantil é perfeito e acabado logo que o comprador e o vendedor se acordam na coisa, no preço e nas condições; e desde esse momento nenhuma das partes pode arrepender-se sem consentimento da outra, ainda que a coisa se não ache entregue nem o preço pago. Fica entendido que nas vendas condicionais não se reputa o contrato perfeito senão depois de verificada a condição (artigo $\mathrm{n}^{\circ}$. 127).

É unicamente considerada mercantil a compra e venda de efeitos móveis ou semoventes, para os revender por grosso ou a retalho, na mesma espécie ou manufaturados, ou para alugar o seu uso; compreendendo-se na classe dos primeiros a moeda metálica e o papel moeda, títulos de fundos públicos, ações de companhias e papéis de crédito comerciais, contanto que nas referidas transações o comprador ou vendedor seja comerciante. (grifamos)

${ }^{8}$ CAVALCANTI, Fernando Geraldo Mendes. Contrato de câmbio de exportação em juízo. Rio de Janeiro: Renovar, 1989. p. 41.

${ }^{9}$ BRASIL. Lei $n$ 10.406, de 10 jan 2002. Código Civil. Art. 481: "Pelo contrato de compra e venda, um dos contratantes se obriga a transferir o domínio de certa coisa, e o outro, a pagar-lhe certo preço em dinheiro".
} 
contrato do qual defluem obrigações recíprocas para cada uma das partes. Dessa forma, verifica-se que os efeitos derivados desse contrato são meramente obrigacionais, e não reais, haja vista que, de acordo com o direito brasileiro, o contrato de compra e venda em si não transfere o domínio da coisa, mas gera, apenas, para o vendedor, a obrigação de transferi-lo, isto é, uma obrigação de dar. Nesse sentido, ensina Orlando Gomes a respeito do contrato de compra e venda:

Seu fim específico é a alienação de um bem. As pessoas que o celebram têm a intenção, respectivamente, de transferir e adquirir a propriedade. Em alguns sistemas jurídicos, o contrato de compra e venda produz, por si só, efeito translativo. Em outros, porém, não é meio hábil para transmitir a propriedade, limitando-se a gerar a obrigação de transferi-la. (...) O Direito pátrio atribui ao contrato de compra e venda efeitos exclusivamente obrigacionais. ${ }^{10}$

À luz do que determina o art. 482 do Código Civil Brasileiro (Lei $10.406 / 02)^{11}$, para se tornar perfeito e acabado, basta que as partes acordem o objeto e o preço do contrato de compra e venda, sendo certo que, desde esse momento, nenhuma das partes pode arrepender-se, sem o consentimento da outra, ainda que a coisa não se ache entregue e nem o preço pago, o que ressalta, portanto, sua natureza de contrato consensual, além de sua bilateralidade.

Não se pode confundir, portanto, o contrato bilateral de compra e venda com o contrato unilateral de mútuo, por exemplo. Realmente, enquanto do acordo de vontades no de compra e venda nasce a obrigação, para o vendedor, de transferir o domínio da coisa e, para o comprador, de pagar o preço, do acordo de vontades do contrato unilateral do mútuo nasce a obrigação, apenas para o mutuário, de devolver a coisa recebida ou coisas do mesmo gênero, qualidade e quantidade. ${ }^{12}$

Além disso, o mútuo é contrato real que só se aperfeiçoa com a entrega da coisa (dinheiro) pelo mutuante ao mutuário, enquanto o contrato

\footnotetext{
${ }^{10}$ GOMES, Orlando. Contratos. $12^{\mathrm{a}}$ ed. Rio de Janeiro: Forense, 1987. p. 244-245.

${ }^{11}$ Art. 482 - A compra e venda, quando pura, considerar-se-á obrigatória e perfeita, desde que as partes acordarem no objeto e no preço.

${ }^{12}$ BRASIL. Lei $n$ 10.406, de 10 jan 2002. Código Civil. Art. 586: "O mútuo é o empréstimo de coisas fungíveis. O mutuário é obrigado a restituir ao mutuante o que dele recebeu em coisa do mesmo gênero, qualidade e quantidade".
} 
de compra e venda é consensual, não sendo necessário, para que o contrato se aperfeiçoe, que se faça a entrega, por ocasião do acordo, da coisa de que se pretende transferir o domínio ou propriedade. Como ensina Washington de Barros Monteiro:

aquele que recebe o empréstimo (e que se denomina mutuário), se torna dona da coisa emprestada, podendo dar-lhe o destino que entender: consumir, alienar, dispor, abandonar. (...), com o mútuo, o que é meu se torna teu (quod ex meo tuum fit). ${ }^{13}$

O contrato de compra e venda pertence, por definição, à categoria dos contratos onerosos, onde vendedor e comprador visam obter vantagem patrimonial, de forma que ao sacrifício da perda da coisa corresponde o proveito do recebimento de algo que lhe é entregue pela outra parte da relação.

A compra e venda é, portanto, um contrato consensual, bilateral, oneroso, em regra comutativo, estando, em alguns casos, sujeito à forma prescrita em lei, que independe, entretanto, na maioria dos casos, de qualquer solenidade.

Considerando que, em tese, podem ser objeto de compra e venda todas as coisas que não estejam fora do comércio, no contrato de câmbio, a moeda transforma-se de instrumento de pagamento em mercadoria, de forma que se reputa a moeda nacional como preço e a moeda estrangeira figura como mercadoria nesse tipo de negócio jurídico.

O artigo 191, $2^{\text {a }}$ alínea, do Código Comercial $^{14}$, hoje revogado, já consagrava essa opinião, haja vista que incluía a moeda metálica e o papelmoeda como possíveis objetos da compra e venda mercantil. Assim, temos, no contrato de câmbio, a situação na qual a moeda estrangeira seria comprada ou vendida mediante pagamento em moeda nacional. Essa tese

\footnotetext{
${ }^{13}$ MONTEIRO, Washington de Barros. Curso de direito civil. Direito das Obrigações. $2^{\mathrm{a}}$ parte. v. 5. $17^{\mathrm{a}}$ ed. São Paulo: Saraiva, 1981-1982. p. 215.

14 "Artigo 191 .... É unicamente considerada mercantil a compra e venda de efeitos móveis ou semoventes, para os revender a grosso ou a retalho, na mesma espécie ou manufaturados, ou para alugar o seu uso; compreendendo-se na classe dos primeiros a moeda metálica e o papel moeda, títulos de fundos públicos, ações de companhia e papéis de crédito comerciais, contanto que nas referidas transações o comprador ou vendedor seja comerciante." (texto não originalmente destacado)
} 
encontra larga aceitação doutrinária, pronunciando-se em seu favor Fábio Konder Comparato, nos seguintes termos:

\begin{abstract}
No câmbio, a moeda transforma-se, de instrumento de pagamento em mercadoria, isto é, um bem econômico sujeito ao mercado e submetido à lei da oferta e da procura. Em nosso Código Comercial, essa opinião tradicional foi consagrada, incluindo-se a moeda metálica e o papel moeda como objetos da compra e venda mercantil (artigo 191, segunda alínea). Assim, a moeda estrangeira seria comprada ou vendida mediante pagamento em moeda nacional. Nos atuais contratos de câmbio, aliás, as partes são designadas 'comprador' e 'vendedor', demonstrando a persistência da mesma análise jurídica da operação. ${ }^{15}$
\end{abstract}

Não custa ressaltar, que apenas a moeda estrangeira pode constituir objeto da compra e venda, haja vista que não faria nenhum sentido econômico a troca de moeda corrente por moeda corrente, sendo que, para que haja compra e venda, tal moeda estrangeira deve ser trocada por moeda nacional.

Podemos configurar o contrato de câmbio de exportação, portanto, como uma venda firme de divisas, não havendo espaço para considerá-lo como uma promessa de venda nem quando da venda a termo, no qual apenas se protela a execução do contrato. Como já explanado acima, para a validação do contrato, não é essencial que o vendedor entregue, imediatamente, a coisa ao comprador e este, no mesmo ato, recebendo-a, lhe pague o preço.

A consensualidade do contrato de compra e venda de câmbio permite que se venda bem futuro e que se venda até bem alheio. Isso quer dizer que, em um contrato de câmbio de exportação celebrado a termo, mesmo inexistindo no tempo do contrato a moeda estrangeira, o exportador poderia vendê-la e a instituição financeira comprá-la.

Celebrado a termo o contrato de câmbio, as obrigações recíprocas de ambas as partes - a entrega das divisas pelo exportador-vendedor e o pagamento do preço pela instituição financeira-compradora - deverão cumprir-se concomitantemente, não no ato em que o contrato se tornou

15 COMPARATO, Fábio Konder. Inadimplemento de Contrato de Câmbio. In: Direito Empresarial. p. 384-385. 
perfeito e acabado, que se dá quando as partes ajustam o preço e o objeto do mesmo, mas até o fim do prazo ajustado.

Todavia, na compra e venda a termo, pode ocorrer que o banco, sem alterar a fisionomia do negócio jurídico de compra e venda, adiante o cumprimento da sua obrigação. Nesse caso, o banco antecipará parte ou a totalidade do preço das divisas compradas, antes do pagamento do valor da exportação pelo importador no exterior. Essa antecipação é conhecida como Adiantamento sobre Contrato de Câmbio (ACC) ${ }^{16}$ e que é objeto de tópico à parte nesta obra.

Deve-se deixar claro, entretanto, que, conforme ressalta o doutrinador Eduardo Salomão Neto:

o adiantamento sobre contrato de câmbio deriva sua natureza do próprio contrato de câmbio. Assim, constitui pagamento antecipado do valor do bem móvel (moeda estrangeira) adquirido e não operação autônoma de empréstimo. ${ }^{17}$

A circunstância de haver tal antecipação parcial ou total do preço, ou seja, o início da parte executiva do contrato pelo banco, não altera a fisionomia do negócio jurídico do contrato de câmbio de exportação que, substancialmente, é a de um contrato de compra e venda.

Logo, como compra e venda, o contrato de câmbio de exportação se insere na classe dos contratos bilaterais ou sinalagmáticos, sendo consensual, oneroso e comutativo e nada tendo de condicional ou aleatório.

Pelo exposto, podemos concluir que o contrato de câmbio de exportação é uma compra e venda de divisas, em regra celebrada a termo, que nasce do mutuo consenso entre as partes. Nesse contrato, uma instituição financeira, autorizada a operar no mercado de câmbio, adquire as divisas de um exportador, a serem entregues no vencimento ajustado contratualmente, e se obriga a pagar-lhe o valor correspondente em moeda nacional.

\footnotetext{
${ }^{16}$ Neste trabalho o termo Adiantamento sobre Contrato de Câmbio muitas vezes será substituído por ACC.

${ }^{17}$ SALOMÃO NETO, Eduardo. Direito Bancário. São Paulo: Atlas, 2007. p. 320.
} 
Resta, portanto, perfeito e acabado logo que o comprador e o vendedor acordem quanto à coisa (divisas ou moeda estrangeira), o preço (equivalência em moeda nacional) e o consentimento (convergência de vontades sobre a coisa, o preço e as demais condições do negócio), quando não haverá mais lugar para arrependimento unilateral.

\subsection{Adiantamentos sobre os Contratos de Câmbio (ACC)}

Conforme visto acima, os bancos que operam com câmbio, podem conceder aos seus clientes exportadores, adiantamentos sobre os contratos de câmbio (ACC), operação que consiste na antecipação parcial ou total dos reais equivalentes à quantidade de moeda estrangeira comprada a termo desses exportadores pelo banco. Considerando que esse adiantamento pode ser parcial ou total, seu valor, para fins e efeitos da Lei do Mercado de Capitais (Lei 4.728, de 14 de julho de 1965), deve ser averbado, com a anuência do exportador-vendedor, no verso do próprio instrumento do contrato de câmbio, ou em separado em formulário padrão do BACEN. Trata-se, portanto, da antecipação do preço da moeda estrangeira que o banco negociador das divisas concede ao exportador.

No ACC tem-se, portanto, nada mais do que mera antecipação da fase de execução do contrato de compra e venda de divisas (contrato de câmbio), sendo que o adiantamento concedido poderá ser efetivado antes da entrega, pelo exportador ao banco, dos documentos concernentes à exportação, ou após tal entrega.

Assim, não há como se configurar no adiantamento o instituto jurídico do "Sinal" ou "Arras" do Direito Civil, pois estes se prestam para garantia da conclusão do negócio, admitindo arrependimento das partes. $\mathrm{O}$ fato das regras do instituto das "Arras" terem sido transferidas, no Código Civil de 2002, da parte que trata do direito dos contratos para a parte do direito das obrigações já demonstra o caráter do instituto de ser uma pré- 
fixação de indenização dos danos sofridos pela parte inocente na hipótese do contrato não vir a ser celebrado.

O artigo Art. 420 do Código Civil, considerando a possibilidade de ser estipulado nos contratos o direito de arrependimento, determina que nesses casos, as arras ou sinal terão a função unicamente indenizatória, ou seja, quem as deu perdê-las-á em benefício da outra parte; e quem as recebeu devolvê-las-á, mais o equivalente.

Tratando dos efeitos deste instituto, Caio Mário é enfático ao determinar que "Dado o sinal, está firmado o negócio". ${ }^{18}$ Enquanto isso, no contrato de câmbio, quando se adianta o preço, por já se encontrar o contrato de compra e venda de câmbio perfeito e acabado, não mais se admite o arrependimento unilateral de qualquer dos contratantes.

Importante destacar, também, que não se trata de operação de crédito, não podendo o adiantamento ser confundido com um financiamento concedido ao exportador nem ser visto como se constituísse um outro contrato, distinto do de compra e venda de câmbio. O Adiantamento, conforme já explanado acima, nada mais é do que a antecipação da fase de execução da compra e venda, com pagamento parcial ou total do preço pelo comprador, não constituindo uma operação de mútuo, mas caracterizando simplesmente uma antecipação parcial ou total do preço da coisa ajustado no contrato de compra e venda de câmbio.

Como bem leciona Fernando G.M. Cavalcanti:

A pedido do exportador e no seu interesse, antecipa o Banco o cumprimento de sua obrigação de pagar o preço, antecipação da fase de execução da compra e venda, inerente aos contratos bilaterais (...). Esta antecipação é o que se chama de adiantamento de contrato de câmbio, não se tratando de um novo contrato, porque só existe um ajuste: o de compra e venda de divisas. ${ }^{19}$

Essa modalidade de operação objetiva proporcionar recursos antecipados ao exportador para que ele possa fazer face às diversas fases do

\footnotetext{
${ }^{18}$ PEREIRA, Caio Mário da Silva. Instituições de direito Civil. v. III. $12^{\mathrm{a}}$ ed. Rio de Janeiro: Forense, 2006. p. 100.

${ }^{19}$ CAVALCANTI, Fernando Geraldo Mendes. Contrato de câmbio de exportação em juízo. Rio de Janeiro: Renovar, 1989. p. 70.
} 
processo de produção e comercialização da mercadoria exportada, constituindo-se assim, num incentivo à exportação. A utilização do ACC, entretanto, muitas vezes é motivada pela oportunidade de conseguir dinheiro (reais) imediatamente, de forma a obter vantagens na aplicação financeira sobre a desvalorização cambial. Tal fato ocorre, quando as taxas de juros domésticas estão elevadas em relação às taxas em dólar, o que incentiva as empresas a tomarem recursos nessas linhas para aplicar os recursos no mercado financeiro, contratando os ACCs para financiar suas atividades.

Para entender exatamente o funcionamento prático do adiantamento em contrato de câmbio para exportação, Eduardo Fortuna explica que:

O ACC poderá ocorrer e desdobrar-se em duas fases. Primeira fase: concessão do adiantamento pelo banco em até 180 (cento e oitenta dias) antes do embarque da mercadoria, caracterizando-se como um financiamento à produção, embora perdendo a desvalorização cambial posterior que possa ocorrer. Segunda fase: a mercadoria já está pronta e embarcada, até 60 dias após o embarque. (...) Entretanto, poderá o exportador (vendedor) requerer o adiantamento da obrigação do banco - antecipação do pagamento em moeda nacional, que deverá, obrigatoriamente, ser averbado no próprio instrumento do contrato de câmbio. ${ }^{20}$

Conforme bem anota referido autor, o Comunicado Bacen/Gecam n. 331, de 01.11.1976, definia esta operação, dizendo, em seu art. 45, que o adiantamento sobre o contrato de câmbio configura uma antecipação parcial ou total, por conta do preço em real da moeda estrangeira comprada a termo, pelo Banco negociador.

Como se vê, se o negócio de exportação correr normalmente, o banco recebe de volta o valor adiantado, tão logo receba a moeda estrangeira remetida pelo banco do importador estrangeiro. Em outras palavras, embora firmado o contrato naquele momento, tornando-se suas cláusulas obrigatórias para ambos os contratantes, o contrato só será considerado executado quando ocorrer o fato futuro consistente na entrega, pelo importador estrangeiro, da moeda estrangeira devida ao exportador

\footnotetext{
${ }^{20}$ FORTUNA, Eduardo. Mercado Financeiro: produtos e serviços. 17 $7^{\mathrm{a}}$ ed. Rio de Janeiro: Qualitymark, 2008. p. 429.
} 
brasileiro. Moeda esta que será entregue por intermédio da instituição bancária que celebrou o contrato de câmbio de exportação no País.

Relembre-se sempre, para evitar confusões no presente exame, que estamos tratando aqui da venda que o exportador brasileiro contrata com o banco brasileiro, vendendo ao banco as divisas estrangeiras que deverá receber do importador estrangeiro no momento em que se completar toda a negociação. Ou seja, venda com pagamento à vista (pelo adiantamento), para entrega futura da mercadoria negociada (mercadoria, no caso, repita-se é a divisa, a moeda estrangeira). 


\section{Capítulo II - O INADIMPLEMENTO DO CONTRATO DE CÂMBIO DE EXPORTAÇÃO}

\subsection{CONSEQÜÊNCIAS JURÍDICAS DA INADIMPLÊNCIA}

Conforme já visto no capítulo anterior, o contrato de câmbio é reconhecido como um dos contratos do gênero da compra e venda, tendo por objeto a negociação de moedas diversas entre as partes, podendo ter acordada sua liquidação futura.

A fim de adentrarmos nas conseqüências jurídicas que podem advir do inadimplemento desse tipo de contrato, vale lembrar, também, que o contrato de câmbio de exportação é, por definição, um contrato oneroso, tendo tanto o vendedor quanto o comprador das divisas negociadas a intenção de obter uma vantagem patrimonial, sendo certo que ao sacrifício da perda da coisa, corresponde o proveito do recebimento do preço.

No que tange ao foco deste trabalho como um todo e ao deste tópico em específico, cabe-nos esclarecer que concentraremos nossa atenção no inadimplemento do contrato de câmbio por parte do cliente do Banco, haja vista sua maior probabilidade de ocorrência, bem como de sua maior representatividade econômica e jurídica.

À luz do disposto no Código Civil Brasileiro, no que tange às conseqüências da inexecução das obrigações em geral, verifica-se que não cumprindo o devedor com a sua obrigação ou fazendo-a fora do esquema acordado, responde perante o credor pelas perdas e danos por este incorridas $^{21}$, da mesma forma em que, por outro lado, exime-se o devedor de responsabilidade por caso fortuito ou força maior se não o houver por eles expressamente se responsabilizado ${ }^{22}$.

\footnotetext{
${ }^{21}$ BRASIL. Lei $n$ 10.406, de 10 jan 2002. Código Civil. Art. 389: "Não cumprida a obrigação, responde o devedor por perdas e danos, mais juros e atualização monetária segundo índices oficiais regularmente estabelecidos, e honorários de advogado".

${ }^{22}$ BRASIL. Lei n 10.406, de 10 jan 2002. Código Civil. Art. 393 - "O devedor não responde pelos prejuízos resultantes de caso fortuito ou força maior, se expressamente não se houver por eles responsabilizado".
} 
Dado o regime de mercado restrito como é o de câmbio, o cliente do banco, diante do não recebimento da moeda estrangeira por parte do importador, poderá enfrentar grandes dificuldades para cumprir com sua obrigação (pois pode não ter acesso ao mercado oficial de câmbio). Diante de tal situação, o credor não terá a opção de demandar o cumprimento específico do contrato, ficando restrito à rescisão do acordo, quando terá direito às perdas e danos se houver sofrido prejuízos com o inadimplemento da obrigação pelo cliente.

Pois bem, em relação ao cliente-exportador, a inadimplência do contrato de câmbio de exportação se caracteriza pela não entrega, dentro do prazo pactuado com a instituição financeira, dos documentos comprobatórios do embarque da mercadoria, ou de quaisquer outros que the sejam exigidos por lei ou contratualmente.

Ressalte-se, todavia, que a efetivação de tal entrega, não retira a responsabilidade do exportador quanto ao adimplemento da sua prestação fundamental nesse contrato, qual seja, a efetiva entrega ao banco das divisas que lhe foram vendidas, de forma que se configura o inadimplemento do cliente-exportador quando o mesmo falha no cumprimento desta obrigação, impedindo, dessa forma, a seqüência na liquidação do negócio, que somente se opera com a real entrega da moeda estrangeira no exterior.

Temos, portanto, que, na realidade, todas as obrigações do cliente, cujo adimplemento esteja atrelado à entrega da moeda ao banco são prestações que, se inadimplidas, mesmo que possam estar vinculadas a outro contrato (ex.: contrato de compra e venda mercantil celebrado entre o exportador brasileiro e o importador estrangeiro), consideram-se obrigações principais do contrato de câmbio de exportação.

O inadimplemento de contrato de câmbio será considerado definitivo quando: (i) for impossível (em função de condições regulamentares) ou negada pelo banco a prorrogação do contrato; ou (ii) não houver condições viáveis para o distrato do acordo. Nessa hipótese, deverá ser feita a baixa da posição cambial, "a qual é ato administrativo ligado ao sistema 
governamental de controle de câmbio", sendo "mera operação cambial interna, destinada ao sancamento da posição de câmbio do estabelecimento comprador da moeda estrangeira". ${ }^{23}$

Cabe ressaltar, entretanto, que, embora seja feita a baixa da posição cambial no âmbito interno do banco, toda vez que este deixar de receber do cliente, em razão do inadimplemento da obrigação contratual deste, a moeda estrangeira dele adquirida, sofrerá um prejuízo. Isso porque, concomitantemente à aquisição da moeda estrangeira do cliente, o banco a recoloca no mercado em razão da sua atividade financeira e em obediência às disposições regulamentares.

Essas disposições impõem aos bancos adquirentes de moeda estrangeira de cliente exportador para liquidação futura, a obrigação de revendê-las em sua maior parte, de forma a impedir aos bancos a especulação em dita moeda. Temos, portanto, que o banco adquire as divisas do exportador para negociá-las logo em seguida com terceiros (importadores), não se configurando como mero entesourador.

Cumpre lembrar aqui, que pelo sistema brasileiro, as divisas são monopólio do Estado, que, representado pelo BACEN, estabelece as condições pelas quais um banco pode operar em câmbio. O BACEN determina, dentre outras obrigações, que os bancos podem comprar e vender moedas estrangeiras livremente ao longo do dia, devendo, entretanto, ao final do dia, manter o nível das compras e vendas de moedas estrangeira dentro de determinados limites regularmente fixados, isto é, devem ter o saldo de sua conta em moedas estrangeiras situado dentro dos limites permitidos de posições compradas e vendidas, sob pena de ter de repassar eventual excesso ou desnivelamento dessa posição cambial ao órgão fiscalizador encarregado de controlar as divisas nacionais de exportação.

Diante disso, temos que a estrutura operacional desse tipo de negócio envolve a compra do câmbio do cliente-exportador pelo banco (compra

\footnotetext{
${ }^{23}$ Como preconizava o Comunicado GECAM 331/76, item 40, in fine.
} 
futura, a termo), com a concomitante venda (a prazo) correspondente de igual quantia, ou pouco inferior, a fim de manter a posição de câmbio da instituição financeira nivelada de acordo com as normas estabelecidas pelo BACEN.

Assim, mesmo que o exportador se torne inadimplente quanto às suas obrigações assumidas no contrato de câmbio de exportação junto ao banco, é certo que este, nas correspondentes vendas assumidas, jamais deixará de cumprir sua obrigação frente a terceiros, mesmo que se veja na desagradável situação de ter de desembolsar aquilo que não recebeu em função do inadimplemento do cliente-exportador, como podemos vislumbrar do ensinamento abaixo:

Assim, desonrado um contrato de câmbio pelo exportador, o banco tem que se refazer comprando, incontinenti, parcela idêntica e, obviamente, obrigando-se a pagar, na aquisição, a cotação do dia (taxa em vigor, conforme Boletim de Taxas do Banco Central), com prejuízo evidente, já que a compra inadimplida e vinculada a outro negócio de venda por cumprir, foi calculada com taxa inferior. ${ }^{24}$

Da mesma forma, corrobora a doutrina de Haroldo Malheiros

\section{Duclerc Verçosa:}

(...) o Banco, ao adquirir moeda futura do exportador, faz a sua venda imediata, pois, de um lado, não tem liberdade administrativa no setor interno para manter uma posição de estoque e, de outro, a moeda estrangeira é sua mercadoria, objeto de operações normais de compra e venda. A negociação feita pelo Banco pode ser 'pronta' ou 'futura' (referindo-me ao contrato de revenda das divisas adquiridas do exportador nacional), neste último caso não havendo necessária coincidência com o prazo de seu recebimento efetivo do cliente, uma vez que a instituição pode recorrer ao sistema de financiamento bancário internacional para o fim de resguardar-se contra eventual 'descoberto cambial'. ${ }^{25}$

A existência desse dano sofrido pelo banco demonstra, portanto, que não existe nenhuma relação entre a baixa da posição cambial realizada no âmbito interno das instituições financeiras, e as relações jurídicas existentes entre banco credor e o exportador inadimplente, o qual poderá ser demandado para que indenize o primeiro.

\footnotetext{
${ }^{24}$ CAVALCANTI, Fernando Geraldo Mendes. Contrato de câmbio de exportação em juízo. Rio de Janeiro: Renovar, 1989. p. 76.

${ }^{25}$ VERÇOSA, Haroldo Malheiros Duclerc. O inadimplemento do contrato de câmbio de exportação. In: Revista de Direito Mercantil. p. 65-66.
} 
A fim de enfatizar o prejuízo sofrido pelo banco e, inclusive, de determinar a medida da indenização cabível, vale lembrar aqui que, em matéria de câmbio, a moeda é para os bancos a mercadoria de seu negócio, sendo por eles compradas e vendidas diariamente. Conforme visto linhas acima, no âmbito dessa negociação de divisas realizada pelas instituições financeiras, vislumbramos que as mesmas ora atuam no pólo comprador ora no pólo vendedor, sendo certo que essas operações são vinculadas entre si.

Isto significa que, a moeda que o banco assumiu o compromisso de entregar no exterior nas condições previamente acertadas e dentro do prazo contratado com algum cliente-importador, é obtida pelo banco na correspondente operação de compra realizada, para entrega pronta ou futura, por meio da qual ele adquire o direito de receber referidas divisas. Ou seja, essas divisas recebidas pelo banco quando atua no pólo comprador do câmbio, serão usadas para o cumprimento das obrigações assumidas pelo mesmo banco nas correspondentes operações de venda que efetivou.

É, em função desta vinculação existente entre as operação de compra e de venda de câmbio, que o inadimplemento do contrato de câmbio pelo cliente-exportador causará graves conseqüências à instituição financeira, haja vista a existência de obrigações imediatas assumidas junto a terceiros pela venda da moeda comprada a futuro do exportador brasileiro, de forma que, como bem ensina, novamente, Haroldo Malheiros Duclerc Verçosa:

ao adquirir uma determinada quantidade de moeda estrangeira de um importador, para entrega futura, o Banco imediatamente faz uma venda pronta (com financiamento de terceiro) ou futura (com financiamento ou sem, dependendo da compatibilidade ou não do prazo de entrega com o do recebimento do cliente) da mesma quantidade de divisas. No vencimento da obrigação, ao mesmo tempo em que não recebe do cliente, está obrigado a fazer a entrega das divisas negociadas a terceiro, a quem as vendeu. É certo que, se o Banco não obteve a moeda estrangeira do cliente, também não pagou a este os cruzados correspondentes e, devendo adquirir divisas para honrar sua obrigação perante terceiro, haverá prejuízo na compra das moedas tão-somente caso eleve-se a cotação da moeda estrangeira em relação à nacional, o que o obrigará a gastar mais cruzados para a aquisição da mesma quantidade de dólares, por exemplo. Nesta parte, o prejuízo do Banco corresponderá à diferença de taxas verificada entre as datas de 
celebração do contrato de câmbio com o cliente até a data em que este, amigável ou judicialmente, faça a efetiva reparação do dano ${ }^{26}$

Nesse cenário, se o exportador não entregar ao banco, no prazo combinado, as divisas que lhe vendeu, o banco ficará em dificuldades para entregar a moeda vendida na operação correspondente que realizou, tendo de se valer de suas linhas de crédito no exterior, junto aos banqueiros estrangeiros, pagando juros de acordo com taxas internacionais. Diante disso, resta claro o prejuízo para o banco oriundo da eventual diferença encontrada entre as taxas nacionais e internacionais ${ }^{27}$.

Cabe aqui ressaltar que se o contrato descumprido já tiver sido prorrogado, o exportador fica obrigado, também, pelo pagamento da indenização, aplicada no sentindo de pena moratória pelo atraso no cumprimento dos contratos, conhecida como "bonificação" devida em razão dos ônus advindos ao banco pelo atraso na entrega das cambiais. A propósito deste tema, inclusive, assim se expressa Vitor Alberto Zerbini:

as prorrogações, embora admitidas, podem ocasionar problemas aos bancos, relacionados com sua posição externa. Isso porque os bancos, com a finalidade de evitar saldos a descoberto junto aos seus correspondentes no exterior, ao contratar operações de câmbio, procuram conjugar os prazos de suas compras futuras com os das vendas a termo. Assim sendo, as prorrogações das compras, sem as correspondentes prorrogações das vendas, provocam um desequilíbrio em sua posição original, forçando-os a desembolsar a moeda vendida antes do recebimento dessa mesma moeda comprada. É claro que, ocorrendo o descoberto, os Bancos pagam os juros sobre os saldos devedores até que se proceda sua regularização. Tais juros, evidentemente, são ressarcidos dos clientes que solicitaram prorrogações das compras. ${ }^{28}$

Logo, vemos que, também nas prorrogações, os bancos podem sofrer prejuízos correspondentes aos juros que devem pagar no exterior, de forma que podemos concluir, juntamente com o já citado autor Haroldo Verçosa, que:

\footnotetext{
${ }^{26}$ VERÇOSA, Haroldo Malheiros Duclerc. O inadimplemento do contrato de câmbio de exportação. In: Revista de Direito Mercantil. p. 67-68.

${ }^{27}$ Essa diferença de taxa trata-se de uma forma de indenização de perdas e danos pelo inadimplemento contratual, fixada por lei (art. 75, § $1^{\circ}$, Lei 4.728/65).

${ }^{28}$ ZERBINI, Vitor Alberto. Cambio e Comércio Exterior - Princípio e Prática. São Paulo: Resenha Universitária, 1975. p. 61.
} 
no inadimplemento de contrato de câmbio de exportação, o Banco pode sofrer prejuízos em três frentes diversas, cuja soma total importa no montante da reparação a ser paga pelo cliente, a saber: diferença da taxa de câmbio entre data do contrato com o cliente e efetivo pagamento por este no futuro; juros e despesas com prorrogações externas de contratos de câmbio e juros e despesas pagos na utilização de linhas de crédito no exterior. ${ }^{29}$

Por fim, caberá ao exportador, ainda, restituir ao banco eventual valor do preço que the tenha sido adiantado através de adiantamentos de contratos de câmbio, acrescido do deságio que tenha sido contratualmente pactuado, calculado sobre esse valor adiantado, como forma de indenização pelo uso do adiantamento do preço.

O grande problema enfrentado para ressarcimento dos prejuízos anteriormente explicitados, reside no nível de prova, que é clara quanto ao que toca à simples constatação da variação para mais da taxa de câmbio, mas dependerá de outros elementos, muitas vezes de difícil comprovação, como quanto ao pagamento dos juros e de outras despesas referentes às linhas de crédito externas.

\subsection{EXECUÇÃO JUDICIAL DO CONTRATO DE CÂMBIO CONTRA DEVEDOR SOLVENTE}

Tendo-se comprovado os prejuízos incorridos pela instituição financeira em razão do inadimplemento do contrato de câmbio pelo clienteexportador, passamos a analisar o meio que deve ser utilizado pelo banco para fins de haver do inadimplente: (i) o eventual valor adiantado como antecipação do preço, mais o deságio incidente sobre tal adiantamento; (ii) a indenização das perdas e danos devida pela resolução do contrato, haja vista a diferença da taxa de câmbio entre a data do contrato com o cliente e o efetivo pagamento por este no futuro; (iii) a bonificação calculada sobre o valor do contrato rescindido; (iv) as despesas incorridas com o protesto do contrato; além de todos os prejuízos que foram elencados no item 2.1 deste capítulo; qual seja, a ação de execução.

\footnotetext{
29 VERÇOSA, Haroldo Malheiros Duclerc. O inadimplemento do contrato de câmbio de
} exportação. In: Revista de Direito Mercantil. p. 69. 


\subsubsection{Contrato de Câmbio como Título Executivo Extrajudicial}

Para fins do ajuizamento da ação de execução do contrato de câmbio inadimplido, cumpre-nos, primeiramente, configurar o mesmo como título executivo, encaixando-o em um dos incisos do art. 585 do $\mathrm{CPC}^{30}$, que elenca os títulos executivos extrajudiciais.

Asseverando a possibilidade de que outros títulos, além daqueles elencados no próprio artigo, sejam considerados títulos executivos extrajudiciais, é claro o inciso VII do mencionado art. 585 ao estabelecer que, para tanto, basta que a lei, expressamente, atribua a eles força executiva, senão vejamos:

Art. 585. São títulos executivos extrajudiciais:

(...)

VII - todos os demais títulos, a que, por disposição expressa, a lei atribuir força executiva. $^{31}$

Este é o caso do contrato de câmbio, porquanto sua executoriedade advém de legislação específica, conforme dispõe o art. 75 da Lei ${ }^{\circ}$ 4.728/65, verbis: "Art. 75 . O contrato de câmbio, desde que protestado por oficial competente para o protesto de títulos, constitui instrumento bastante para requerer a ação executiva". ${ }^{32}$

\footnotetext{
${ }^{30}$ Art. 585. São títulos executivos extrajudiciais:

I - a letra de câmbio, a nota promissória, a duplicata, a debênture e o cheque;

II - a escritura pública ou outro documento público assinado pelo devedor; o documento particular assinado pelo devedor e por duas testemunhas; o instrumento de transação referendado pelo Ministério Público, pela Defensoria Pública ou pelos advogados dos transatores;

III - os contratos garantidos por hipoteca, penhor, anticrese e caução, bem como os de seguro de vida;

IV - o crédito decorrente de foro e laudêmio;

V - o crédito, documentalmente comprovado, decorrente de aluguel de imóvel, bem como de encargos acessórios, tais como taxas e despesas de condomínio;

VI - o crédito de serventuário de justiça, de perito, de intérprete, ou de tradutor, quando as custas, emolumentos ou honorários forem aprovados por decisão judicial;

VII - a certidão de dívida ativa da Fazenda Pública da União, dos Estados, do Distrito Federal, dos Territórios e dos Municípios, correspondente aos créditos inscritos na forma da lei;

VIII - todos os demais títulos a que, por disposição expressa, a lei atribuir força executiva.

${ }^{31}$ BRASIL. Lei n 5.869, de 11 jan 1973. Institui o Código de Processo Civil. Art. 585.

${ }^{32}$ BRASIL. Lei n 4.728 , de 14 jul 1965. Disciplina o mercado de capitais e estabelece medidas para o seu desenvolvimento. Art. 75 .
} 
José da Silva Pacheco, em artigo intitulado "Do contrato de câmbio como título executivo", assentou:

\begin{abstract}
Se o exportador-vendedor não adimplir, no prazo, a sua obrigação de entregar ao Banco a moeda estrangeira ou equivalente, pode o Banco promover a respectiva cobrança pela via executiva, por força do disposto no artigo 585 , VII, combinado com o artigo 75 da Lei $\mathrm{n}^{\circ} 4.728$, de 1965.

Realmente, o artigo 75 da Lei $n^{0} \mathbf{4 . 7 2 8 / 6 5}$ não só considera o contrato de câmbio como título executivo, mas também autoriza a cobrança dos adiantamentos realizados por conta dele, sendo legítima a cobrança quer do vendedor da moeda, que pode ser a firma exportadora, quer do co-obrigado, garante ou fiador, que pode ser diretor daquela. ${ }^{33}$ - grifamos
\end{abstract}

Teses contrárias a esse entendimento, entretanto, defendem que para se garantir a executoriedade do contrato de câmbio, o mesmo deve estar assinado por duas testemunhas, em obediência ao disposto inciso II do art. 585 do CPC que estabeleceria essa obrigatoriedade nos seguintes termos:

Art. 585. São títulos executivos extrajudiciais:

(...)

II - a escritura pública ou outro documento público assinado pelo devedor; o documento particular assinado pelo devedor e por duas testemunhas; o instrumento de transação referendado pelo Ministério Público, pela Defensoria Pública ou pelos advogados dos transatores $;^{34}$

Em relação a esse argumento, cabe-nos voltar à análise ao conteúdo do próprio inciso VII do art. 585. Este artigo, ao estabelecer que são títulos executivos todos os demais títulos a que, por disposição expressa, a lei atribuir força executiva, deixa transparecer claramente que o legislador separou essa hipótese daquela prevista no inciso II, que exige a assinatura de 2 testemunhas.

Quisesse o legislador manter essa exigência para os títulos cuja força executiva advém de outras leis, o teria acrescentado no inciso VII a mesma exigência do inciso II, sendo certo que não pode exigir o intérprete o que a lei não exigiu. Dessa forma, entendemos que o inciso II somente se refere ao documento particular não contemplado como título executivo em lei especial.

\footnotetext{
${ }^{33}$ PACHECO, José da Silva. Do contrato de câmbio como título executivo. In: Informativo Semanal 16/99, ADV - Advogacia Dinâmica. p. 246-247.

${ }^{34}$ BRASIL. Lei n 5.869, de 11 jan 1973. Institui o Código de Processo Civil. Art. 585, II.
} 
Ademais, temos que o contrato de câmbio é um contrato diferenciado, regido por leis próprias e que mereceu da legislação tratamento especial, outorgando-lhe exeqüibilidade mediante mero protesto. Considerando-se que a lei não tem palavras inúteis, podemos vislumbrar no art. 75 da Lei $n^{\circ} 4.728 / 65$, que o contrato de câmbio é título executivo "desde que protestado por oficial competente", nada mais lhe sendo exigido para tanto, dispensando-se, portanto, a assinatura de duas testemunhas.

No mesmo sentido, a Ministra Nancy Andrigh, nos autos do REsp n ${ }^{\circ}$ 298.816/BA, DJU de 28.3.2001, asseverou contra a alegação de que os contratos de câmbio, na categoria de documento particular, devessem ser subscritos por duas testemunhas, da seguinte forma:

Nos termos do inciso VII, do art. 585, do CPC, são títulos executivos extrajudiciais todos os demais títulos, a que, por disposição expressa, a lei atribuir força executiva. Ao permitir a outorga de força executiva a documentos que não foram elencados pelo CPC, o legislador exigiu apenas que, tal outorga, ocorresse por meio de lei e de forma expressa. O art. 75, da Lei $\mathrm{n}^{\circ} 4.728 / 65$, de forma expressa, atribuiu força executiva aos contratos de câmbio, desde que devidamente protestados, de forma a restarem atendidas as exigências do inciso VII do art. 585 do CPC.

Resta examinar a alegação dos recorrentes no sentido de que, com o advento do atual CPC, o art. 75 , da Lei $n^{\circ} 4.728 / 65$, foi revogado. Não houve revogação expressa de tal dispositivo, e tampouco se vislumbra ser hipótese de revogação tácita, uma vez que não há incompatibilidade com as normas do CPC, estando, inclusive, em harmonia com o art. 586, do CPC, o qual exige que os títulos executivos sejam dotados dos atributos de liquidez, certeza e exigibilidade.

Oportuna a lição do em. doutrinador Vicente Greco Filho:

'É preciso, porém, fazer uma ressalva quanto a diplomas legais que instituíram executividade de títulos ou créditos antes da vigência do Código de Processo Civil. Nestes casos, somente persiste a executoriedade se o título cumpre os requisitos do art. 586, ou seja, que seja líquido, certo e exigível; caso contrário, deve entender-se o dispositivo legal como revogado, como comentamos quanto às despesas de condomínio cobradas pelo condomínio contra o condômino. ${ }^{35}$

Desta feita, podemos assegurar que o contrato de câmbio tem força executiva decorrente de disposição expressa de lei e, por isso, configura título executivo extrajudicial com base no art. 585, VII, do CPC c/c o art. 75 da Lei n ${ }^{\circ} 4.728 / 65$, sendo dispensável a assinatura de testemunhas.

\footnotetext{
${ }^{35}$ BAHIA. Tribunal de Justiça. Recurso Especial no 298.816. 2001/0001754-1. Relatora Ministra Nancy Andrighi. Publicação em 28 mar 2001. Decisão em 13 fev 2001.
} 
Logo, descumprido o contrato de câmbio pelo exportador-vendedor das divisas e, sendo este solvente, deve o banco-comprador, com vistas à execução do mesmo, providenciar o prévio e obrigatório protesto do contrato de câmbio inadimplido, conforme determinação legal.

Ainda sobre a questão ligada ao contrato de câmbio ser título executivo, faz-se necessária uma breve explanação da obrigação consubstanciada no mesmo quanto a sua (a) certeza, (b) liquidez e (c) exigibilidade:

(a) A certeza subjetiva neste tipo de contrato é evidente desde o momento de celebração do negócio, quando as partes contratantes são perfeitamente identificadas, com o pólo credor e o devedor no contrato bem definidos. A certeza objetiva diz respeito à identificação da prestação devida, que, no caso, é sempre de dar coisa certa, isto é, dinheiro. Logo, temos a obrigação como certa;

(b) No vencimento do contrato, o valor do mesmo é claramente encontrado haja vista que se trata de um negócio de compra e venda em que o preço fora acordado desde sua constituição, sendo certo que a eventual necessidade de cálculos aritméticos para determinação de encargos, não afastam a liquidez do título executivo;

(c) Por fim, a exigibilidade - ausência de óbice ao gozo do direito constante do título -, na prática, representa obrigação vencida e não honrada. Para que a dívida oriunda do contrato de câmbio seja exigível, portanto, deve-se tê-la como certa quanto a sua existência, vencida (quando restará configurado o inadimplemento, conforme já explanado ao longo deste trabalho) e não sujeita a termo ou condicionante.

\subsubsection{Protesto do Contrato de Câmbio}

No que tange ao protesto de títulos de crédito e de outros documentos de dívida, cabe esclarecer, inicialmente, que compete privativamente ao Tabelião de Protesto de Títulos a prática de todos os atos 
relativos ao protesto, cabendo-lhe efetivar a protocolização, expedir a intimação ao devedor, acatar a desistência formalizada pelo apresentante, o recebimento do pagamento, a lavratura e o registro do protesto, a averbação da retificação de erros materiais pelo serviço, proceder ao cancelamento do registro do protesto e prestar informações e fornecer certidões relativas a todos os atos praticados.

No contrato de câmbio, como já visto, com o consentimento das partes, manifestado pelo preenchimento e assinaturas do contrato, a operação se perfaz. Frente ao inadimplemento do cliente-exportador, caso não haja o entendimento amigável para o cancelamento do contrato de câmbio e respectivo reembolso do montante devido em função da inadimplência, tem o banco comprador de câmbio o direito de encaminhar o contrato a protesto, junto ao Oficial competente, com vistas ao processo de execução.

Nesse ponto, já o ensinava a doutrina de J. X. Carvalho de Mendonça:

A falta de liquidação da operação a prazo sobre cambiais, no tempo devido, obriga à indenização por perdas e danos. Como medida assecuratória do seu direito, a parte lesada pode interpor protesto. Esta providência não tem outro fim que o de constituir em mora o contratante inadimplente. ${ }^{36}$

A prova da inadimplência e do descumprimento de obrigação originada no contrato de câmbio se dá por meio do protesto, que resolve o contrato de câmbio, passando-o a não ser mais considerado para fins de composição do saldo das contas que compõem a posição de câmbio das instituições financeiras, de forma que não se pode mais falar em entrega das divisas, mas apenas em perdas e danos a serem arbitradas em reais. Temos então o protesto como medida assecuratória de prestação de perdas e danos pelo não cumprimento do contrato, sendo o único meio de que dispõe o banco comprador para efetivar a apuração e cobrança da indenização devida pelo inadimplemento do contrato de câmbio. Por fim, cabe-nos reiterar que

\footnotetext{
${ }^{36}$ MENDONÇA apud CAVAlCANTI, Fernando Geraldo Mendes. Contrato de câmbio de exportação em juízo. Rio de Janeiro: Renovar, 1989. p. 77.
} 
o contrato de câmbio protestado é retirado da posição de câmbio do banco, para fins de execução da rotina diária de conformidade.

Disciplinando o contrato de câmbio, a Lei 4.728/65 entrou em vigor em 16/06/1965 e, visando fortalecer e por todos os meios garantir a liquidez dos bancos e das instituições financeiras, estipulou no caput do seu art. 75, que o contrato de câmbio "desde que protestado por oficial competente para o protesto de títulos, constitui instrumento bastante para requerer a ação executiva”. Referido dispositivo legal faz do instrumento de câmbio, conforme já explanado no tópico precedente, um título de crédito, líquido e certo, que deve ser sempre pactuado por escrito e que é sujeito a protesto no caso de não cumprimento pelo obrigado da prestação a que se vinculou.

Temos, portanto, que a regra processualística estabelecida no art. 75 Lei 4.728/65 é simples e objetiva ao determinar o protesto do instrumento do contrato de câmbio como pressuposto para o ajuizamento de ação executiva. Nesse sentido:

\footnotetext{
ADIANTAMENTO POR CONTA DE CONTRATO DE CÂMBIO. PROTESTO. SUSTAÇÃO. INADMISSIBILIDADE, NO CASO.

- O protesto do contrato de câmbio é condição indispensável à propositura da execução (art. 75 da Lei n. 4.728, de 14.7.1965).

- Sustação do protesto somente admissível em circunstâncias excepcionais, não presentes na espécie em exame.

Recurso especial conhecido e provido. ${ }^{37}$
}

A propositura da ação de execução com base no contrato de câmbio tem, portanto, como pressuposto legal, o protesto do contrato inadimplido, de forma que, ao realizar o protesto do mesmo, o Banco está agindo em regular exercício do seu direito de credor, assegurando a integridade e liquidez do seu direito. Trata-se, portanto, de protesto obrigatório, necessário, exigido por força de lei, tirado para documentar a mora e impontualidade do devedor.

Essa obrigatoriedade, entretanto, não ocorre na hipótese, a ser abordada cuidadosamente no capítulo seguinte desta obra, de falência ou

\footnotetext{
${ }^{37}$ BRASIL. Superior Tribunal de Justiça. REsp 536128 / RS. Julgamento em 13 dez 2005. Ministro Relator Barros Monteiro. Quarta Turma.
} 
recuperação judicial do exportador-vendedor, quando a instituição financeira deverá valer-se da ação especial de Restituição prevista na Lei de Falência (Lei. 11.101/05), para reaver a importância porventura adiantada ao exportador, tornando-se desnecessário o protesto do contrato de câmbio para o ingresso da referida ação em juízo, por falta, inclusive, de determinação legal para tanto.

Realmente, com clareza se nota que, enquanto os dois primeiros parágrafos do art. 75 da Lei $4.728 / 65$ se referem, expressamente, ao rito executivo para as cobranças previstas, o $3^{\circ}$ tal não fez, porque no seu caso, se opera uma mera restituição de bem de terceiro em poder do falido, senão vejamos:

Art. 75 - O contrato de câmbio, desde que protestado por oficial competente para o protesto de títulos, constitui instrumento bastante para requerer a ação executiva.

$\S 1^{\circ}$ Por esta via, o credor haverá a diferença entre a taxa de câmbio do contrato e a da data em que se efetuar o pagamento, conforme cotação fornecida pelo Banco Central, acrescida dos juros de mora.

$\S 2^{\circ}$ Pelo mesmo rito, serão processadas as ações para cobrança dos adiantamentos feitos pelas instituições financeiras aos exportadores, por conta do valor do contrato de câmbio, desde que as importâncias correspondentes estejam averbadas no contrato, com anuência do vendedor.

$\S 3^{\circ}$ No caso de falência ou concordata, o credor poderá pedir a restituição das importâncias adiantadas, a que se refere o parágrafo anterior.

$\S 4^{\circ}$ As importâncias adiantadas na forma do $\S 2^{\circ}$ deste artigo serão destinadas, na hipótese de falência, liquidação extrajudicial ou intervenção em instituição financeira, ao pagamento das linhas de crédito comercial que lhes deram origem, nos termos e condições estabelecidas pelo Banco Central do Brasil. ${ }^{38}$

Salienta-se que o protesto necessário, poderá ocorrer imediatamente em razão do inadimplemento da obrigação de entrega dos documentos de exportação exigidos na data aprazada, haja vista que tal fato acarreta a antecipação do vencimento contratual, de acordo com cláusula obrigatória inserida nos contratos de câmbio.

É da máxima importância se ter presente que, sendo obrigatório o protesto do contrato de câmbio, inadmissível é a sua sustação, como costumeiramente se requer judicialmente, mediante medida cautelar de

\footnotetext{
${ }^{38}$ BRASIL. Lei $n$ 4.728, de 14 jul 1965. Disciplina o mercado de capitais e estabelece medidas para o seu desenvolvimento. Art. 75 .
} 
sustação de protesto. A inadmissibilidade de tal sustação já é proclamada pela jurisprudência pátria em termos expressos, senão vejamos: "é inadmissível a concessão de liminar, em cautela, para sustar o protesto de contrato de câmbio, porque tal protesto constitui condição indispensável ao exercício da ação de execução (Lei no 4.728/65, art. 75)" ${ }^{39}$

$\mathrm{Ou}$, mais especificamente:

APELAÇ̃̃O CÍVEL. AÇ̃̃O CAUTELAR INOMINADA. CONTRATO DE CÂMBIO. SUSTAČ̃̃O DE PROTESTO. VIABILIDADE SOMENTE QUANDO DEMONSTRADAS CIRCUNSTÂNCIAS EXCEPCIONAIS. VARIAÇÃO DA COTAÇÃO DO DÓLAR AMERICANO NOS ANOS DE 2005 E 2006. SITUAÇÃO NOTÓRIA. ONEROSIDADE EXCESSIVA E IMPREVISIBILIDADE QUE NÃO SE VERIFICAM. AUSÊNCIA DE FUMUS BONI IURIS. SENTENÇA MANTIDA. RECURSO DESPROVIDO. O protesto do contrato de câmbio é condição indispensável à propositura da execução (art. 75 da Lei n. 4.728, de 14.7.1965). - Sustação do protesto somente admissível em circunstâncias excepcionais, não presentes na espécie em exame. Recurso especial conhecido e provido. ${ }^{40}$

São pressupostos necessários à propositura e ao provimento das ações cautelares: o fumus boni iuris e o periculum in mora. ${ }^{41}$

\subsubsection{Procedimento para Execução do Contrato de Câmbio}

Feita essa abordagem sobre os principais pontos atinentes à execução do contrato de câmbio, vemos que a Lei de Mercado de Capitais (Lei 4.728/65), dando liquidez e certeza ao contrato de câmbio, possibilitou à instituição compradora de câmbio - diante do descumprimento do contrato pelo exportador-vendedor das divisas, sendo este solvente, e após esgotados os meios persuasivos de cobrança - a providenciar o prévio e obrigatório protesto do referido contrato inadimplido, com vistas à sua execução. Resolvido o contrato pelo protesto e providenciada a baixa contábil da posição, estará apto o banco a ajuizar o processo de execução forçada para

\footnotetext{
${ }^{39}$ BRASIL. Superior Tribunal de Justiça. REsp 36.681-0/RS (1993/0018772-4 - 07/02/1994). Rel. Min. Antônio Torreão Braz. $4^{\mathrm{a}}$ Turma. Publicação no DJ em 7 fev 1994.

${ }^{40}$ BRASIL. Superior Tribunal de Justiça. REsp n. 536.128/RS. Rel. Min. Barros Monteiro. Publicado no DJ em 3 abr 2006.

${ }^{41}$ SANTA CATARINA. Tribunal de Justiça. Ap. Cív. n. 2006.018334-0. Rel. Des. Salim Schead dos Santos. Publicado no DJ em 29 mar 2007.
} 
haver do inadimplente os valores devidos em razão do instrumento contratual.

Referida execução é do contrato de câmbio, envolvendo, como já visto acima, os demais acessórios, como deságio, bonificação, etc., decorrentes que são da concessão de adiantamentos e da resolução do contrato.

Com vistas a facilitar o entendimento do trâmite a ser percorrido para a execução do contrato de câmbio, podemos exemplificar o procedimento da seguinte forma: (i) tendo o Cliente exportador inadimplido com sua obrigação de entrega das cambiais de exportação dentro do prazo estipulado, configura-se, em razão de estipulação contratual, o vencimento antecipado de todas as obrigações assumidas pelo Cliente no contrato de câmbio; (ii) diante disso, deve o Banco comprador das divisas, notificar o devedor a pagar, dentro determinado prazo, o valor devido na forma do contrato e da lei; (iii) vencida e não paga a dívida pelo devedor, deve a instituição credora proceder, nos termos avençados no contrato, à baixa, junto ao Banco Central do Brasil, das respectivas posições cambiais em aberto; (iv) ato contínuo, devem os devedores serem notificados acerca do ocorrido e também intimados a pagar o equivalente à efetiva baixa do contrato, mais os acréscimos contratuais e legais; (v) em observância às formalidades previstas no art. 75 da Lei 4.728/65, deve o Banco levar o contrato a protesto, observando o requisito legal da intimação dos devedores; e (vi) por fim, deve o banco ingressar com a ação de execução por título extrajudicial.

A petição inicial do processo de execução deve ser instruída com os contratos originais de câmbio, onde deve constar a imprescindível averbação dos eventuais adiantamentos concedidos, com os instrumentos dos protestos obrigatórios, bem como um demonstrativo da dívida atualizada, informando o valor total atualizado da dívida vencida.

Eventuais erros no demonstrativo de cálculos acostados à inicial da ação de execução de contrato de câmbio, podem implicar em 
reconhecimento de excesso de execução, sem, contudo, retirar a liquidez do contrato, não desnaturando, com isso, o caráter executivo do mesmo ${ }^{42}$. Como se vê, o demonstrativo juntado à execução não integra o título. Nesse sentido, há seguinte precedente do STJ:

\begin{abstract}
EMBARGOS À EXECUCC̃̃O. RECURSO ESPECIAL. TÍTULO EXECUTIVO EXTRAJUDICIAL. NULIDADE. INEXISTÊNCIA. LIQUIDEZ. CÁLCULOS ARITMÉTICOS. PREQUESTIONAMENTO. NECESSIDADE. CONTRATAÇÃO EM MOEDA ESTRANGEIRA. VALIDADE. SUCUMBÊNCIA RECÍPROCA. SÚMULA 07/STJ.

1. A realização de meros cálculos aritméticos não compromete a inteireza da prestação jurisdicional e a liquidez do título.

2. Conforme reiterada jurisprudência desta Corte, mesmo as matérias de ordem pública não dispensam o requisito do prequestionamento.

3. Se há previsão no sentido de que o pagamento será feito em moeda nacional, é válida a contratação em moeda estrangeira.

4. A verificação da ocorrência de sucumbência recíproca demanda incursão no conjunto fático-probatório dos autos, pois depende da análise do reflexo do deferimento parcial dos embargos no resultado concreto da demanda.

5. Recurso especial não conhecido. ${ }^{43}$
\end{abstract}

\title{
2.2.3.1 Medidas Acautelatórias
}

Apesar da instauração da execução, como se sabe, muitas vezes, ao final, se frustra a investida judicial, se antes não forem, cautelarmente, tomadas providências que garantam a satisfação do crédito exigido. Dessa forma, conseguindo demonstrar-se, nos autos, o risco da instituição financeira não ter o seu crédito pago (em razão do devedor estar com acentuado e crescente grau de endividamento, ou incorrendo em prática de defraudação da garantia, ou demonstrando a grave crise financeira por que passa o devedor), cabe ressaltar, que pode a instituição credora requerer, liminarmente, medidas acautelatórias de arresto de bens do devedor.

Como se sabe, as recentes reformas do CPC tiveram como objetivo aumentar a efetividade do processo de execução. Entre as diversas alterações, merecem ser mencionadas (i) a que transferiu ao credor o direito de nomear bens à penhora já na inicial (art. 652, §2 do CPC), (ii) a que

\footnotetext{
${ }^{42}$ BRASIL. Lei n 5.869, de 11 jan 1973. Texto compilado Institui o Código de Processo Civil. Art. $586 \mathrm{c} / \mathrm{c} 585$, II.

${ }^{43}$ BRASIL. Superior Tribunal de Justiça. REsp 900.680/SP. Rel. Ministro Fernando Gonçalves. Quarta Turma. Julgado em 1 abr 2008.
} 
possibilitou ao credor, antes mesmo da citação, averbar a existência da execução "no registro de imóveis, registro de veículos ou registro de outros bens sujeitos à penhora" (art. 615-A do CPC) e (iii) a que, expressamente, permitiu ao Juiz, por meio eletrônico, determinar a indisponibilidade de ativos financeiros em nome do executado, até o limite do valor executado, a fim de "possibilitar a penhora de dinheiro em depósito ou aplicação financeira" (art. 655-A do CPC).

Nesse contexto de efetividade do processo executivo, insere-se a possibilidade do Juiz deferir medidas acautelatórias urgentes, na forma do art. 615 do $\mathrm{CPC}^{44}$. Evidentemente, grande parte da efetividade da execução deve-se ao elemento surpresa, de forma a evitar que o devedor oculte-se ou realize manobras para esvaziar o seu patrimônio antes que possa ser empregado para satisfazer a dívida contraída. Assim, com fundamento no art. 615, III do CPC, que sempre permitiu ao credor "pleitear medidas acautelatórias urgentes", é que se pode requerer que seja deferido, liminarmente, o arresto de bens do devedor.

Vejam-se, sobre o alcance dessas medidas, os ensinamentos de Humberto Theodoro Júnior:

O inciso III do art. 615 concede ao exeqüente a faculdade de 'pleitear medidas acautelatórias urgentes'. Trata-se de uma simples reafirmação do poder geral de cautela adotado amplamente nos arts. 796 e seguintes (processo cautelar).

É o caso, por exemplo, de arresto de bens móveis, quando o devedor está ausente e sua citação pode demorar, com risco de desaparecimentos fraudulento de garantia, ou de depósito de bens abandonados e em riso de deterioração (arts. 798 e 799), e outras situações análogas.

Essa faculdade o credor poderá exercitar na própria petição inicial, ou em petição avulsa, e independerá de abertura de um processo cautelar separado.

As medidas, in casu, são simples incidentes da execução e visam a assegurar a prática dos atos executivos do processo em andamento. ${ }^{45}$

\footnotetext{
${ }^{44}$ Art. 615. Cumpre ainda ao credor:

I - indicar a espécie de execução que prefere, quando por mais de um modo pode ser efetuada;

II - requerer a intimação do credor pignoratício, hipotecário, ou anticrético, ou usufrutuário, quando a penhora recair sobre bens gravados por penhor, hipoteca, anticrese ou usufruto;

III - pleitear medidas acautelatórias urgentes;

IV - provar que adimpliu a contraprestação, que Ihe corresponde, ou que Ihe assegura o cumprimento, se o executado não for obrigado a satisfazer a sua prestação senão mediante a contraprestação do credor".

${ }^{45}$ THEODORO JÚNIOR, Humberto. Curso de Direito Processual Civil. v. II. $42^{\mathrm{a}}$ ed. Rio de Janeiro: Forense, 2007. p. 240-241.
} 
O deferimento desse eventual pedido encontra, vale dizer, apoio na doutrina. Como ensina Araken de Assis:

\begin{abstract}
Independentemente da disciplina própria das ações cautelares, concebem-se outras medidas, cautelares ou satisfativas, no curso do processo executivo. São essas medidas que o dispositivo autoriza. Distinguem-se as medidas propriamente cautelares das satisfativas pela circunstância de que as primeiras não entregam o bem da vida.

Seja como for, ambas as medidas, cautelares e satisfativas, cabem no processo executivo. Por exemplo: o bloqueio do crédito em conta corrente bancária do executado, enquanto flui o prazo para a nomeação de bens (art. 652), porque o dinheiro se situa em primeiro lugar na ordem de nomeação insculpida no art. 655, I, e sua falta de indicação implicaria a ineficácia do ato, a teor do art. 656, I, conjugado ao risco de o executado fazer desaparecer a importância naquele interregno, é medida cautelar inserida na órbita do art. 615 , III. ${ }^{46}$
\end{abstract}

Em reforço à essa posição doutrinária, Luiz Rodrigues Wambier,

Flávio Renato Correia de Almeida e Eduardo Talamini ensinam que:

O exeqüente tem a possibilidade de, na inicial, pleitear 'medidas acautelatórias de caráter urgente', nos termos do art. 615, III. A especial importância desse preceito está em autorizar a concessão das providências cautelares, no próprio processo de execução - e não em específico processo cautelar, como usualmente teria de ser (art. 796 e seguintes). ${ }^{47}$

E, para não haver dúvida:

Sendo pedido e provado pelo exeqüente já na petição inicial o perigo de ineficácia em razão da citação do executado, a penhora on line liminar tomará certa natureza cautelar, em algo próximo do arresto cautelar, medida de constrição de bens que visa garantir a eficácia do processo de execução de pagar quantia certa. $O$ sincretismo processual que passou a adotar o ordenamento processual brasileiro, com as últimas reformas permite que esse pedido liminar seja feito independentemente de uma ação autônoma cautelar de arresto. ${ }^{48}$

A jurisprudência, da mesma forma, autoriza o arresto na própria execução, em atenção à norma do art. 615, III do CPC e para garantir a efetividade da cobrança forçada:

CUMULAÇÃO DE CAUTELAR E AÇÃO PRINCIPAL. EXECUÇÃO E ARRESTO. Presentes os requisitos autorizadores da cautela, e considerados a natureza instrumental do processo e o disposto no inc. III do art. 615 do CPC,

\footnotetext{
46 ASSIS, Araken de. Comentários do Código de Processo Civil. v. VI. Rio de Janeiro: Forense, 1999. p. 328-329.

${ }^{47}$ WAMBIER, Luiz Rodrigues; CORREIA DE ALMEIDA, Flávio Renato; TALAMINI, Eduardo. Curso Avançado de Processo Civil. v. 2. São Paulo: Revista dos Tribunais, 1998. p. 145.

${ }^{48}$ NEVES, Daniel Amorim Assumpção. Reforma do CPC. v. 2. São Paulo: Revista dos Tribunais, 2007. p. 287-288.
} 
nada obsta cumule o credor, no ajuizamento da pretensão executória, pedido cautelar de arresto. Este, após as citações e fluido o prazo do art. 633, resolver-seá em penhora. ${ }^{49}$

-.-.-.-.-.-.-.-.-.-

EXECUÇÃO CUMULADA COM MEDIDA CAUTELAR DE ARRESTO ADMISSIBILIDADE ANTE A PRESENÇA DOS REQUISITOS ESPECÍFICOS - ART. 615, III, DO CPC - A possibilidade de cumulação da cautelar de arresto, com ação de execução forçada, está expressa no art. 615, inc. III, do Código de Processo Civil. ${ }^{50}$

Especificamente sobre a possibilidade de, com base no art. 615, III do CPC, postular-se o arresto de bens já quando se instaurar a execução, vale a pena citar outro julgado, dessa vez do e. Tribunal de Justiça de São Paulo:

AGRAVO DE INSTRUMENTO - BENS ARRESTADOS EM PROCESSO DE EXECUÇÃO - POSSIBILIDADE - INTELIGÊNCIA DO ART. 615, III, DO CPC - A cumulação da cautelar de arresto com a ação de execução forçada, está prevista no art. 615, inc. III, do Código de Processo Civil, corolário do poder geral de cautela inerente ao órgão jurisdicional, uma vez que a cautela processual abrange qualquer tipo de processo, seja de conhecimento, seja de execução. ${ }^{51}$

Nesse julgado, o Tribunal deixou consignado que, tendo em vista a natureza instrumental do processo, não se mostra razoável a apresentação de pedido cautelar apartado, pois, o que se tem como imprescindível é que os requisitos autorizadores da cautela sejam demonstrados e se façam presentes, bem como que o pedido cumulado com o principal esteja em sintonia com os preceitos legais. Enfatiza o mencionado acórdão paulista que o credor poderá exercitar essa faculdade na própria petição inicial, ou em petição avulsa, e independerá de abertura de um processo cautelar separado, mesmo porque, a liminar de arresto é simples incidente no processo executivo e visa assegurar a efetividade dos atos executivos do processo.

Dessa forma, conclui-se que, no curso da ação executiva, é lícito ao credor pleitear medidas acautelatórias urgentes, não existindo nenhum óbice

\footnotetext{
${ }^{49}$ RIO GRANDE DO SUL. JTARS 61/198.

${ }^{50}$ MINAS GERAIS. Tribunal de Justiça. Apel. Cív. 479.785-3, Rel. Des. Tarcísio Martins Costa.

${ }^{51}$ SÃO PAULO. Tribunal de Justiça. AI 7.172.643-3, 24 ${ }^{\mathrm{a}}$ CCTJ. Rel. Des. Roberto Mac Cracken. Julgado em 25 out 2007.
} 
que as mesmas possam ser requeridas já na própria inicial ou no curso do processo, quando tais medidas mostrarem-se necessárias.

O STJ, inclusive, admite o arresto na execução, deferido de ofício e sem audiência da parte:

PROCESSUAL CIVIL - PODER GERAL DE CAUTELA DO JUIZ ARRESTO. I - JURISPRUDENCIA DO STJ ACOLHE ENTENDIMENTO NO SENTIDO DE QUE ARRESTO DECRETADO PELO JUIZ DA EXECUÇÃO, DE OFÍ́CIO, NO EXERCÍCIO DE SEU PODER GERAL DE CAUTELA E PARA GARANTIA DO PROCESSO E EFICÁCIA DA DECISÃO É CABÍVEL E PODER SER EFETIVADO SEM AUDIÊNCIA DA PARTE ADVERSA. ${ }^{52}$

Tendo sido estabelecido acima o trâmite que o banco credor de contrato de câmbio, inadimplido por devedor solvente, pode se valer para reaver seu crédito, ressalta-se, por fim, que o banco comprador, em representação e garantia da operação de câmbio, habitualmente aceita notas promissórias de emissão do cliente exportador, devidamente avalizadas. Diante do inadimplemento do contrato de câmbio, o banco normalmente executa as referidas notas promissórias contra os avalistas, concomitante ou sucessivamente à execução do contrato de câmbio. Nesse caso, entretanto, deve a instituição financeira ressaltar, em ambas as execuções, a existência dos dois processos, comprometendo-se a comunicar a qualquer dos juízos os recebimentos eventuais do outro, para prova de boa-fé.

Diante de tudo que fora acima exposto, vemos que o credor de contrato de câmbio, cumprindo com as exigências contratuais e legais para a constituição do título executivo, pode se valer da ação de execução forçada por título extrajudicial contra o devedor solvente para fins de reaver seu crédito oriundo do contrato inadimplido.

Considerando a especificidade da matéria quando de se trata de execução do contrato de câmbio em casos de devedor falido ou em recuperação judicial, separamos um capítulo específico dessa obra para tratar do assunto.

\footnotetext{
${ }^{52}$ BRASIL. Superior Tribunal de Justiça. REsp 122583/RS. Rel. Ministro Waldemar Zveiter. Terceira Turma. Julgado em 17 fev 1998. Publicado no DJ em 4 mai 1998.
} 


\section{Capítulo III - A RECUPERAÇÃO DO CRÉDITO DO CONTRATO DE CÂMBIO DE EXPORTAÇÃO QUANDO DA FALÊNCIA OU RECUPERAÇÃO JUDICIAL DO DEVEDOR- EXPORTADOR}

\subsection{BREVE CONTEXTO DA NORMA ATINENTE À MATÉRIA}

O financiamento à exportação mereceu a atenção do legislador tanto na hipótese de falência quando na de recuperação judicial do exportador financiado. Desde o advento da Lei n. 4.728 em 14 de julho de 1965, é assegurado às instituições financiadoras da exportação o direito à restituição dos valores adiantados com base num contrato de câmbio quando da falência do exportador (art. $75, \S 2^{\circ}$ e $\$ 3^{\circ}$ da Lei $\left.4.728 / 65\right)^{53}$.

De acordo com a linguagem consubstanciada na atual Lei de Falência datada de 2005, podemos afirmar que o financiamento à exportação fundado em um contrato de câmbio é tratado, na falência do exportador, como crédito extraconcursal, de forma que, como será visto mais pormenorizadamente linhas abaixo, o crédito decorrente desse contrato é atendido antes de iniciar-se o concurso de credores do falido.

Numa operação de ACC não lastreada em recursos provenientes do exterior, a garantia do banco financiador é baseada na estrutura negocial que envolve a operação, senão vejamos: com base no contrato de câmbio, o banco compra as divisas a que o exportador brasileiro tem direito em

\footnotetext{
53 "Art. 75. O contrato de câmbio, desde que protestado por oficial competente para o protesto de títulos, constitui instrumento bastante para requerer a ação executiva.

$\S 1^{\circ}$ Por esta via, o credor haverá a diferença entre a taxa de câmbio do contrato e a da data em que se efetuar o pagamento, conforme cotação fornecida pelo Banco Central, acrescida dos juros de mora.

$\S 2^{\circ}$ Pelo mesmo rito, serão processadas as ações para cobrança dos adiantamentos feitos pelas instituições financeiras aos exportadores, por conta do valor do contrato de câmbio, desde que as importâncias correspondentes estejam averbadas no contrato, com anuência do vendedor.

$\S 3^{\circ}$ No caso de falência ou concordata, o credor poderá pedir a restituição das importâncias adiantadas, a que se refere o parágrafo anterior.

$\S 4^{0}$ As importâncias adiantadas na forma do $\S 2^{2}$ deste artigo serão destinadas na hipótese de falência, liquidação extrajudicial ou intervenção em instituição financeira, ao pagamento das linhas de crédito comercial que lhes deram origem, nos termos e condições estabelecidos pelo Banco Central do Brasil".
} 
decorrência da venda das mercadorias por ele exportadas. Realizando o adiantamento dos reais ao cliente-exportador, a garantia do banco é o recebimento do preço dessas mercadorias, cujo pagamento será feito pelo comprador estrangeiro.

$\mathrm{Se}$, porém, antes da entrega ou embarque das mercadorias e conseqüente vencimento da obrigação do comprador estrangeiro, ocorrer a falência do cliente-exportador, nenhuma divisa será entregue ao banco que procedeu à antecipação, que perde, assim, a garantia de que dispunha. Nessa hipótese, por ser um crédito extraconcursal, tem a instituição financeira que procedeu ao adiantamento em favor do exportador direito à restituição do valor antecipado.

Pois bem, na medida em a lei determina que os bancos não precisam concorrer com os demais credores do cliente-exportador quando da falência deste último, reduz-se o risco de crédito incorrido pela instituição financeira associado à falência do exportador, haja vista que são aumentadas as chances de recuperação do valor financiado, mesmo na hipótese de quebra do devedor. Desse modo, minimizado esse risco, pode a instituição financeira praticar taxas de juros menores nesses financiamentos, não computando nas mesmas o risco correspondente à insolvência do exportador, barateando-se, com isso, essa linha de financiamento e, conseqüentemente, estimulando a exportação.

Como ensina Manoel Justino Bezerra Filho:

(...) esta restituição estabelecida no $\S 3^{\circ}$ do art. 75 da Lei $4.728 / 65$ teve por finalidade assegurar uma garantia extra aos bancos que atuam no contrato de câmbio, colocando a instituição financeira em posição privilegiada relativamente aos demais credores do concordatário e do falido, pretendendo desta forma incentivar as exportações, no afã de conseguir o maior número de divisas em moeda forte externa. Em que pese a posição do privilégio na qual é colocado o crédito do banco (e os privilégios, em princípio, são odiosos), a verdade é que a lei, muitas vezes, funciona como instrumento de estímulo para determinado tipo de atividade comercial, o que ocorre no caso. Concedendo um verdadeiro privilégio ao banco, pretendeu o legislador dar estímulo ao mesmo banco para 
que se coloque em posição de conceder o adiantamento com maior facilidade e, desta forma, incentivar a exportação. ${ }^{54}$

Sobre o tema, anota Silva Pacheco que:

com a finalidade de facilitar o financiamento das exportações do país, (a lei) armou os créditos oriundos de adiantamentos feitos pelas instituições financeiras aos exportadores, por conta do valor de contrato de câmbio, de poderem ensejar o pedido de restituição na concordata ou falência do devedor. ${ }^{55}$

Diante disso, podemos vislumbrar que a finalidade evidente do mencionado dispositivo legal foi a de facilitar o financiamento das exportações do País, para cuja política de desenvolvimento é indispensável o estímulo e, conseqüentemente, a ampliação da exportação de seus produtos. Não tem cabimento, portanto, a alegação no sentido de que se consubstancia um tratamento discriminatório injustificável entre credores, haja vista que a desigualdade verificada é resultante do fim econômico a que visa o contrato de câmbio, que, possuindo um interesse público intrínseco, autoriza tratamento diverso para o meio que facilita sua execução. Assim há que se interpretar o art. $75, \S 3^{\circ}$ da Lei n. 4.728/65 como mais um incentivo às exportações, opção da época em que editado, quando o lema de toda publicidade oficial era - "Exportar é a solução".

\subsection{PEDIDO DE RESTITUIÇÃO}

Um dos objetivos do processo falimentar é a definição dos bens que integram o ativo do falido, para que, com base na verificação dos seus ativos e passivos, possa-se proceder o rateio proporcional entre os credores, na forma estabelecida na lei. Para atingir tal meta, conjuga-se o ato de arrecadação dos bens existentes do devedor, através da constrição judicial do patrimônio do falido, com o procedimento da restituição.

\footnotetext{
${ }^{54}$ BEZERRA FILHO, Manoel Justino. A restituição ao banco do valor do adiantamento efetuado em contrato de câmbio de exportação, em caso de falência ou concordata do exportador - Exame da Súmula 133 do STJ. RT 765/121.

${ }^{55}$ PACHECO, José da Silva. Processo de Falência e Concordata. $8^{\text {a }}$ ed. Rio de Janeiro: Forense, 1998.
} 
Essa conjugação se deve ao fato de que o ato de arrecadação engloba além dos bens de propriedade do falido, os bens que se encontram em sua posse, mas que não lhe pertencem, como se depreende da leitura do artigo 110 da Lei 11.101/05 ${ }^{56}$. Dessa forma, a definição do ativo do falido deve ser complementada pela restituição desses bens aos seus respectivos proprietários.

Evidentemente, no âmbito da execução concursal falimentar, os credores não podem ser satisfeitos com a liquidação de bens que não integram o patrimônio do devedor, sendo que o meio procedimental adequado para retirar esses bens da massa arrecadada é o pedido de restituição.

$\mathrm{Na}$ verdade, o pedido de restituição importa em reclamar da Massa Falida aquilo que não the pertence, sendo instituto mais amplo que a reivindicação do direito civil, já que se pode fundar não apenas em direito real, mas ainda em contrato, ou, como afirma J. C. Sampaio de Lacerda, o pedido de restituição consiste de: "desintegrar da massa falida aquilo que, segundo a lei autoriza, não deve ser mantido no acervo arrecadado, de modo a impedir o enriquecimento ilícito da massa.". ${ }^{57}$

Historicamente, o pedido de restituição destinava-se apenas a tutelar os direitos do proprietário de bem indevidamente arrecadado na falência.

56 “Art. 110. O auto de arrecadação, composto pelo inventário e pelo respectivo laudo de avaliação dos bens, será assinado pelo administrador judicial, pelo falido ou seus representantes e por outras pessoas que auxiliarem ou presenciarem o ato.

$\S$ 1o Não sendo possível a avaliação dos bens no ato da arrecadação, o administrador judicial requererá ao juiz a concessão de prazo para apresentação do laudo de avaliação, que não poderá exceder 30 (trinta) dias, contados da apresentação do auto de arrecadação.

§ 2o Serão referidos no inventário:

I - os livros obrigatórios e os auxiliares ou facultativos do devedor, designando-se o estado em que se acham, número e denominação de cada um, páginas escrituradas, data do início da escrituração e do último lançamento, e se os livros obrigatórios estão revestidos das formalidades legais;

II - dinheiro, papéis, títulos de crédito, documentos e outros bens da massa falida;

III - os bens da massa falida em poder de terceiro, a título de guarda, depósito, penhor ou retenção; IV - os bens indicados como propriedade de terceiros ou reclamados por estes, mencionando-se essa circunstância.

$\S 30$ Quando possível, os bens referidos no § 2o deste artigo serão individualizados.

$\S 4$ o Em relação aos bens imóveis, o administrador judicial, no prazo de 15 (quinze) dias após a sua arrecadação, exibirá as certidões de registro, extraídas posteriormente à decretação da falência, com todas as indicações que nele constarem".

${ }^{57}$ SAMPAIO DE LACERDA, J.C. Manual de Direito Falimentar. $13^{\mathrm{a}}$ ed. Rio de Janeiro: Freitas Bastos, 1996. p. 161. 
Tanto assim, que, na lei de 1945, o lesado tinha a alternativa de optar entre o pedido de restituição e os embargos de terceiro (Dec-Lei 7.661/45, art. 79 e $\left.\S 1^{\circ}\right)^{58}$. O pedido de restituição era, nesse contexto inicial, apenas o procedimento falimentar apropriado e mais célere para resolverem-se eventuais excessos no ato de constrição judicial dos bens do falido, de forma que este instituto era conhecido como instrumento de depuração da massa falida já que se retirava do conjunto de bens arrecadados aqueles que não integravam o patrimônio do falido, embora se encontrassem na sua posse.

Na atual Lei de Falência (Lei 11.101/05) não há mais a possibilidade de opção entre o pedido de restituição e os embargos de terceiro, sendo este último mantido apenas em caráter residual, ou seja, quando não for possível o pedido de restituição.

Dentre as hipóteses de pedido de restituição previstas na atual Lei de Falência, encontra-se a constante do $\$ 3^{\circ}$ do art. 75 da Lei 4.728/65 que diz respeito à restituição de adiantamento ao exportador feito com base num contrato de câmbio.

Conforme já visto exaustivamente ao longo desta obra, o art. 75 da Lei 4.728/65 estabelece que "o contrato de câmbio, desde que protestado por oficial competente para o protesto de títulos, constitui instrumento bastante para requerer a ação executiva", dizendo ainda seu $\S 3^{\circ}$ que "no caso de falência ou concordata, o credor poderá pedir a restituição das importâncias adiantadas, a que se refere o parágrafo anterior", sendo que o $\S 2^{\circ}$ (anterior) fala sobre "... os adiantamentos feitos pelas instituições financeiras aos exportadores, por conta do valor do contrato de câmbio...".

Mencionado artigo permite que as instituições financeiras façam adiantamentos aos exportadores do preço da moeda estrangeira que compram deles, sendo, portanto, antecipações do valor do contrato de

\footnotetext{
58 "Art. 79 - Aquele que sofrer turbação ou esbulho na sua posse ou direito, por efeito da arrecadação ou do seqüestro, poderá, se não preferir usar do pedido de restituição (art. 76), defender os seus bens por via de embargos de terceiro.

$\S 1^{\circ}$ Os embargos obedecerão à forma estabelecida na lei processual civil".
} 
câmbio que é uma compra e venda bilateral, consensual, comutativa e onerosa. Resta permitido, portanto, que as instituições financeiras, nas hipóteses do $\S 2^{\circ}$, se utilizem da ação de cobrança, via executiva, contra o devedor solvente e, no caso de falência $\left(\$ 3^{\circ}\right)$, da ação de restituição. A exegese do $\S 3^{\circ}$ pressupõe a falência do exportador que acarreta em que o Banco que adiantara as somas, nada receberá, ressoando justa a restituição.

Nesses casos, a restituição é necessariamente em dinheiro, haja vista que os adiantamentos de contratos de câmbio têm por objeto determinada soma em dinheiro. Ressalta-se que o Supremo Tribunal Federal já sumulou entendimento a favor da possibilidade de ser o dinheiro, bem fungível por excelência, objeto de pedido restituitório, conforme Súmula 417, verbis: Pode ser objeto de restituição, na falência, dinheiro em poder do falido, recebido em nome de outrem, ou do qual, por lei ou contrato, não tivesse ele a disponibilidade".

Conforme doutrina de Rubens Requião:

Em síntese, o primeiro efeito do pedido é, precisamente, a suspensão da disponibilidade da cousa, e, em seguida, a restituição, exista em espécie ou tenha sido sub-rogada por outra. Não existindo, nem uma, nem outra, por ter sido vendida ou consumida, restitui-se o respectivo preço. A restituição do valor, expresso no preço, deve ser pago desde logo, fora do rateio, antes de qualquer credor, mesmo privilegiado, pois constitui valor de terceiro, resultante de sua propriedade privada, que deve ser preservada. ${ }^{59}$

A jurisprudência do STJ é pacífica no sentido do reconhecimento do direito à restituição das quantias relativas a adiantamento de contrato de câmbio, tal como previsto no art. $75, \S 3^{\circ}$, da Lei 4.728/65, acrescidas de correção monetária (Súmula $36 / \mathrm{STJ})^{60}$ e independentemente de a antecipação ter sido efetuada nos quinze dias anteriores ao requerimento da falência (Súmula 133/STJ) ${ }^{61}$, afirmando, ainda, sua prioridade em relação a quaisquer créditos da massa, porquanto representam, na verdade, dinheiro

\footnotetext{
${ }^{59}$ REQUIÃO, Rubens. Curso de Direito Falimentar. v. I. $11^{\text {a }}$ ed. São Paulo: Saraiva, 1986. p. 247.

${ }^{60}$ Súmula 36/STJ: "A correção monetária integra o valor da restituição, em caso de adiantamento de cambio, requerida em concordata ou falência."

${ }^{61}$ Súmula 133/STJ: "a restituição da importância adiantada, a conta de contrato de cambio, independe de ter sido a antecipação efetuada nos quinze dias anteriores ao requerimento da concordata."
} 
de terceiro em poder da pessoa jurídica do devedor. ${ }^{62}$ Nesse sentido, são os seguintes precedentes jurisprudenciais:

Falência. Pedido de restituição de adiantamento- Contrato de câmbio. Preferência. Créditos Trabalhistas. Assentado na jurisprudência da Terceira Turma o entendimento segundo o qual o pagamento das restituições ordenadas decorrentes de adiantamento de contrato de câmbio, deve ser efetuado de imediato, antes de qualquer crédito, mesmo privilegiado. Tal não constitui propriamente, encargos ou dívidas da massa, mas sim, dinheiro de terceiro, embora arrecadado no poder do falido, não integrante de seu patrimônio. Recurso conhecido e provido. ${ }^{63}$

COMERCIAL. CONCORDATA. CONTRATO DE CÂMBIO. RESTITUIÇÃO DE QUANTIAS ADIANTADAS. SÚMULA 133, DO STJ. PREFERÊNCIA COM RELAÇÃO AO CRÉDITO TRABALHISTA. PRECEDENTES.

- A restituição da importância adiantada, à conta de contrato de câmbio, independe de ter sido a antecipação efetuada nos quinze dias anteriores ao requerimento da concordata. (Súmula 133, do STJ). - Os valores devidos à título de restituição de adiantamento de contrato de câmbio devem ser pagos antes dos créditos trabalhistas. Recursos especiais não conhecidos. ${ }^{64}$

Diante disso, vemos que a Lei criou uma hipótese sui generis de restituição de dinheiro, não a condicionando ao fato de ter sido arrecadada a importância a restituir. A instituição financeira que pede a restituição é satisfeita com o dinheiro do caixa geral da massa e não com os bens que tenham sido adquiridos com os valores adiantados.

Conforme já mencionado no primeiro tópico deste Capítulo, por caracterizarem-se como credores extraconcursais, os titulares do direito de restituição não entram na classificação dos credores da Lei de Falência, devendo receber seu pagamento antes de qualquer outro, por mais privilegiado que seja (exceção apenas ao adiantamento dos salários em atraso, nos limites legais) ${ }^{65}$, sob pena de, invertendo-se essa ordem, se estar

\footnotetext{
${ }^{62}$ BRASIL. Superior Tribunal de Justiça. RESP 533.522/RS. $4^{\mathrm{a}}$ Turma. Rel. Min. Fernando Gonçalves. Publicado no DJ em 3 nov 2003.

63 BRASIL. Superior Tribunal de Justiça. RESP 56133/RS. $3^{\text {a }}$ Turma. Rel. Min. Waldemar Zveiter. Publicado no DJ de 21 ago 1995.

${ }^{64}$ BRASIL. Superior Tribunal de Justiça. REsp 227708 / SC. Rel. Min. Cesar Asfor Rocha. $4^{\mathrm{a}}$ Turma. Julgamento em 21 mar 2000.

${ }^{65}$ Essa exceção advém da conjugação dos artigos 86, parágrafo único com o 151, ambos da Lei 11.101/05, senão vejamos:

“Art. 86. Proceder-se-á à restituição em dinheiro:

(...)

II - da importância entregue ao devedor, em moeda corrente nacional, decorrente de adiantamento a contrato de câmbio para exportação, na forma do art. $75 \S \S 3^{\circ}$ e a, da Lei ${ }^{\circ} 4.728$, de 14 de julho
} 
satisfazendo crédito mediante execução de bem não integrante do patrimônio do devedor. Logo, ao atribuir ao credor por adiantamentos de câmbio o beneficio da restituição, a Lei n 4.728/65, exclui este "crédito" (crédito dito "lato sensu") de qualquer disputa de preferência ou de rateio com os demais credores.

Sendo assim, não cabe situar os titulares de direito de restituição no quadro de credores da massa, em cujo âmbito têm preferência, indiscutivelmente, os créditos trabalhistas, seguidos dos créditos com garantia real, dos fiscais, e assim por diante, até os créditos quirografários. Isso porque a retirada da massa falida dos bens que, por determinação legal, dela não fazem parte, mesmo estando em seu poder, com a conseqüente entrega dos mesmos a seus titulares, antecede logicamente a qualquer medida tendente ao rateio para satisfação dos credores, entre as quais as de classificação dos créditos e de organização do quadro de credores.

Nas palavras da doutrina de Rubens Requião, o pedido de restituição constitui-se:

no mecanismo que o Estado concede ao interessado, que possui bens próprios em poder do devedor falido, proporcionando-lhe meios de reavê-los, impedindo que seja engolfados no vértice do patrimônio do falido, pois não integram a garantia comum dos credores. Somente, pois, os bens do devedor insolvente constituem, de fato, a garantia dos credores. ${ }^{66}$

Logo, o direito à restituição das importâncias adiantadas, que surge com a decretação da falência, não se sujeita ao concurso de credores, pois importa reclamar da massa falida aquilo que não lhe pertence, sendo certo que os valores objeto da restituição não fazem parte da garantia comum dos credores da massa.

de 1965, desde que o prazo total da operação, inclusive eventuais prorrogações, não exceda o previsto nas normas específicas da autoridade competente;

(...)

Parágrafo único. As restituições de que trata este artigo somente serão efetuadas após o pagamento previsto no art. 151 desta Lei.

(...)

Art. 151. Os créditos trabalhistas de natureza estritamente salarial vencidos nos 3 (três) meses anteriores à decretação da falência, até o limite de 5 (cinco) salários-mínimos por trabalhador, serão pagos tão logo haja disponibilidade em caixa".

${ }^{66}$ REQUIÃO, Rubens. Aspectos modernos do Direito Comercial. v. 2. São Paulo: Saraiva, 1980. p. 358. 
Portanto, se o adiantamento efetuado no contrato de câmbio é passível de restituição, e sobre tal questão esperamos não restar a menor dúvida, pois assim assevera a própria lei, a quantia adiantada não pertence à massa falida, que apenas a detém temporariamente, sendo que se o credor está reivindicando coisa própria, é evidente que tal bem deve ser, incontinenti, devolvido ao seu legítimo proprietário, independentemente de participação em rateio com credores comuns da massa falida. $\mathrm{Ou}$, como afirma Pontes de Miranda, "quem restitui dá, porém dá o que não é seu, nem de terceiro, e sim do próprio credor" ${ }^{\natural 7}$.

Cabe ressaltar aqui, que de acordo com o Código Civil, se o credor é também o proprietário, tem ele assegurado o direito de reaver seus bens de quem quer que injustamente os possua ${ }^{68}$. Neste sentido, Carvalho de Mendonça: "O dono da cousa não é credor de quem a possui; tem um 'jus in re'; não um 'jus in rem', ou melhor, não a recebe em pagamento, a título de credor, mas em restituição, a título de propriedade" 69

Por fim, para encerramos esse tópico, servimo-nos de um apanhado dos ensinamentos de Rubens Requião:

\begin{abstract}
Assim, os bens em espécie, e certos créditos arrecadados em mãos do falido, mas pertencentes a terceiros, são imediatamente restituíveis por determinação ou sentença judicial. Se forem bens consumidos, sub-rogam-se no valor correspondente, ou se forem créditos de adiantamentos feitos por instituições financeiras aos exportadores, por conta do valor do contrato de câmbio, deverá o síndico imediatamente pagá-los independentemente do estágio em que se encontra o processo falimentar. Tenha-se sempre em conta que esse bem ou valor não pertence à massa falida, mas integra o patrimônio do terceiro dele desapossado. Se o dinheiro correspondente não for encontrado, o pagamento se fará então logo que for financeiramente possível à massa falida, sem que seja incluído oficialmente no quadro geral dos credores. (...) Se não houver, entretanto, recursos para tanto, em poder da massa falida, deverá a importância objeto da restituição, logo que possível, ser paga, após a realização do ativo, antes de qualquer crédito, mesmo que seja preferencial. Como valor pertencente à propriedade de terceiro, não pode constituir valor da massa falida garantia dos credores, seja de qual força for. (...) Assim, sendo a coisa ou crédito de domínio
\end{abstract}

\footnotetext{
${ }^{67}$ MIRANDA, Pontes de. Tratado de Direito Privado. v. 22. Rio de Janeiro : Borsoi, 1958. p 2.695 .

${ }^{68}$ BRASIL. Lei $n$ 10.406, de 10 jan 2002. Art. 1.228: "O proprietário tem a faculdade de usar, gozar e dispor da coisa, e o direito de reavê-la do poder de quem quer que injustamente a possua ou detenha".

${ }^{69}$ CARVALHO DE MENDONÇA - Tratado, v. 8. p. 274.
} 
de terceiro resultante de dívida proveniente do bem ou valor restituível, que se consumiu, não pode ser classificado como crédito sujeito a rateio, nem como dívida da massa. Não está, vale repetir, sujeito a rateio, nem deve compor o quadro de credores, e jamais como quirografário. É simplesmente um bem, ou o seu valor em dinheiro, que não integra o patrimônio do falido, pois a outrem evidentemente pertence. ${ }^{70}$

\subsection{RECUPERAÇÃO DO CRÉDITO CONTRA DEVEDOR- EXPORTADOR FALIDO}

Tendo sido vistas as nuances que envolvem o pedido de restituição, cabe-nos averiguar o trâmite a ser percorrido pelo banco para fins de recebimento do seu crédito decorrente do contrato de câmbio quando da falência do cliente exportador.

Inicialmente, cumpre-nos esclarecer que a sentença declaratória da falência afasta a incidência das normas dos outros ramos de direito (civil, comercial, consumidor) a que se submetia a relação jurídica da qual o falido participava, fazendo com que os contratos dos quais este fosse parte submetam-se às regras específicas do direito falimentar. Com isso, temos que, ao ser decretada a falência do cliente exportador, o procedimento que visa o recebimento do crédito decorrente do contrato de câmbio, deverá obedecer a determinadas regras específicas.

Conforme já explicado no capítulo precedente desta obra, na hipótese do contrato de câmbio estar vencido quando da decretação da falência e o cliente inadimplente quanto à sua obrigação de entrega dos documentos de exportação, o banco comprador das divisas, independentemente do protesto do contrato, ajuizará pedido de restituição das importâncias antecipadas do preço, com base nos $\S s 2^{\circ}$ e $3^{\circ}$, do art. 75 , da Lei 4.728, cujo teor determina o seguinte:

Art. 75. O contrato de câmbio, desde que protestado por oficial competente para o protesto de títulos, constitui instrumento bastante para requerer a ação executiva. (...)

\footnotetext{
${ }^{70}$ REQUIÃO, Rubens. Aspectos modernos do Direito Comercial. v. 2. São Paulo: Saraiva, 1980. p. 367-371.
} 
$\S 2^{\circ}$ Pelo mesmo rito, serão processadas as ações para cobrança dos adiantamentos feitos pelas instituições financeiras aos exportadores, por conta do valor do contrato de câmbio, desde que as importâncias correspondentes estejam averbadas no contrato, com anuência do vendedor.

$\S 3^{\circ}$ No caso de falência ou concordata, o credor poderá pedir a restituição das importâncias adiantadas, a que se refere o parágrafo anterior. ${ }^{71}$

Essa ação de restituição, que é uma ação autônoma e corre em autos apartados, será processada em conformidade com o disposto no Capítulo V, Seção II da Lei de Falência (Lei 11.101/05), onde é previsto que o juiz da falência mandará autuar em separado o requerimento com os documentos que o instruírem e determinará a intimação do falido, do Comitê, dos credores e do administrador judicial para que, no prazo sucessivo de 5 dias, se manifestem, valendo como contestação a manifestação contrária à restituição.

De acordo com a referida Lei, contestado o pedido e deferidas as provas porventura requeridas, o juiz designará audiência de instrução e julgamento, se necessária (se não houver provas a se realizar, os autos serão conclusos para sentença). A sentença que reconhecer o direito do requerente determinará a entrega da coisa no prazo de 48 horas, sendo certo que, na hipótese de não haver contestação, a massa não será condenada ao pagamento de honorários advocatícios.

Cabe ressaltar que o valor de que se pede a restituição é o da importância entregue ao devedor, em moeda corrente nacional, decorrente do adiantamento ao contrato de câmbio para exportação, que deverá ser atualizado pela correção monetária conforme entendimento sumulado pelo Superior Tribunal de Justiça, nos termos do enunciado da Súmula n 36: “A correção monetária integra o valor da restituição, em caso de adiantamento de cambio, requerida em concordata ou falência."

Por óbvio, não pode ser negada a incidência da correção monetária, haja vista que o objeto da devolução oriunda do pedido de restituição é a medida do quanto vale o adiantamento realizado, e não o dinheiro adiantado

\footnotetext{
${ }^{71}$ BRASIL. Lei $n$ 4.728, de 14 jul 1965. Disciplina o mercado de capitais e estabelece medidas para o seu desenvolvimento. Art. $75, \S \S 2^{\circ}$ e $3^{\circ}$.
} 
em si, ou seja, o objeto da devolução é o valor do dinheiro adiantado devidamente atualizado. Nesse sentido:

Realmente, se não incidir a correção monetária sobre todo adiantamento, todo o tempo decorrido, a restituição verdadeiramente não se operará. $\mathrm{O}$ que for restituído será um valor muito menor do que o que foi adiantado, com visível e injusto prejuízo para o autor da ação. ${ }^{72}$

Os acessórios do contrato (diferença de taxa, deságio, bonificação) e despesas correlatas (protesto - para casos de execução sobrestada por falência -, IOC - Imposto sobre Operação de Crédito recolhido em razão da resolução do contrato, e juros de mora), por sua vez, não são podem ser objeto do pedido de restituição, sendo a Lei expressa no sentido de que o objeto do pedido de restituição deve ser a quantia equivalente ao valor do adiantamento efetuado. Dessa forma, esses acessórios e despesas correlatas devem ser habilitados como créditos quirografários na falência do exportador, sendo certo que aqui também incide correção monetária sobre a totalidade da habilitação, calculada da data do vencimento do contrato até o da sua efetiva liquidação.

Tendo visto este procedimento, cabe-nos averiguar agora a hipótese na qual o contrato de câmbio ainda não esteja vencido quando da decretação da falência. Para tanto, inicia-se esta análise com o disposto no artigo 117 da Lei de Falência, in verbis:

\begin{abstract}
Art. 117. Os contratos bilaterais não se resolvem pela falência e podem ser cumpridos pelo administrador judicial se o cumprimento reduzir ou evitar o aumento do passivo da massa falida ou for necessário à manutenção e preservação de seus ativos, mediante autorização do Comitê.

$\S 1^{\circ} \mathrm{O}$ contratante pode interpelar o administrador judicial, no prazo de até 90 (noventa) dias, contado da assinatura do termo de sua nomeação, para que, dentro de 10 (dez) dias, declare se cumpre ou não o contrato.

$\S 2^{\mathrm{o}}$ A declaração negativa ou o silêncio do administrador judicial confere ao contraente o direito à indenização, cujo valor, apurado em processo ordinário, constituirá crédito quirografário. ${ }^{73}$
\end{abstract}

De acordo com este dispositivo legal, os contratos bilaterais ou sinalagmáticos não se resolvem pela falência de uma das partes, sendo certo

\footnotetext{
${ }^{72}$ CAVALCANTI, Fernando Geraldo Mendes. Contrato de câmbio de exportação em juízo. Rio de Janeiro: Renovar, 1989. p. 106.

${ }^{73}$ BRASIL. Decreto-Lei n 7.661, de 21 jun 1945. Lei de Falências. Art. 117.
} 
que o sentido deste comando normativo é o de estabelecer a faculdade dos órgãos da falência (administrador judicial autorizado pelo Comitê, quando existente) de desconstituírem a relação contratual julgada desinteressante para a massa. Ressalta a Lei, entretanto, que esses contratos só podem ser cumpridos pelo administrador judicial se o cumprimento dos mesmos for proporcionar redução do passivo, evitar seu aumento ou for necessário à preservação do ativo da massa falida.

Com isso, temos que a falência não provoca, a princípio, a rescisão dos contratos do falido, exceto no caso acima visto de contrato bilateral não executado ou unilateral, cujo cumprimento não acarretaria em redução do passivo, nem evitaria seu aumento ou preservaria seu ativo. Nas demais hipóteses, em tese, o contrato deve ser cumprido pelo contratante.

A rescisão de um contrato bilateral pela decretação da falência condiciona-se, portanto, ao fato de que nenhuma das partes tenha dado início ao cumprimento das obrigações por ela assumidas no respectivo contrato. Ou seja, mesmo que definidos como bilaterais pelo direito obrigacional comum, os contratos que já tiverem tido sua execução iniciada por qualquer das partes, excluem-se da possibilidade de serem rescindidos pela decretação da falência.

Nesse sentido é a doutrina de Fábio Ulhoa Coelho:

Em suma, a falência do contratante pode provocar a rescisão do contrato em que ambas as partes assumem obrigações (sinalagmáticos) se a sua execução ainda não teve início por nenhuma delas e daquele em que somente uma das partes (unilaterais) se obrigou. Se a falida ou o outro contratante já haviam iniciado a execução do contrato bilateral, cumprindo parcial ou totalmente as obrigações contraídas, a falência não poderá importar a rescisão. ${ }^{74}$

Esse seria o caso do contrato de câmbio que tenha contemplado um adiantamento por parte da instituição financeira ao cliente. Isto é, firmado um ACC entre banco e cliente e vindo este último a falir, o contrato, em tese, não poderia ser rescindido haja vista o início da execução do mesmo pelo banco que adiantou as divisas ao cliente.

\footnotetext{
${ }^{74}$ COELHO, Fábio Ulhoa. Comentários à nova Lei de Falências e de recuperação de empresas: Lei n. 11.101, de 9-2-2005. $2^{\mathrm{a}}$ ed.. - São Paulo: Saraiva, 2005. p. 315.
} 
Não obstante, são freqüentes os contratos empresariais celebrados com cláusula prevendo a resolução automática do pacto caso um dos contratantes entre em regime falimentar. A questão acerca da validade dessa cláusula resolutiva por falência, por muito tempo dividiu tanto a doutrina quanto a jurisprudência.

Os que defendem a validade da cláusula argumentam que, por se tratar de lei de direito comercial, a Lei de Falência seria formada por normas de natureza subsidiária em relação à vontade das partes, de forma que a norma legal não seria aplicada na hipótese em que os contratantes estipulassem cláusula em sentido contrário. Nesse sentido é a doutrina de Fábio Ulhoa Coelho:

Se as partes pactuaram cláusula de rescisão por falência, está é válida e eficaz, não podendo os órgãos da falência desrespeitá-la. O direito falimentar, como capítulo do direito comercial, tem normas contratuais de natureza supletiva da vontade dos contratantes; seus preceitos sobre obrigações contratuais só se aplicam se as partes nçao convencionaram diferentemente. Assim, o contrato se rescinde não por força do decreto judicial, mas pela vontade das partes contratantes, que o elegeram como causa rescisória do vínculo contratual. ${ }^{75}$

Por outro lado, há quem entendia que dito entendimento era equivocado por acreditar que na medida em que visam a proteção da ordem econômica e, portanto, de interesses da coletividade, as normas da lei falimentar seriam de aplicação imperativa. Nesse sentido, a liberdade dos contratantes não seria tão ampla a ponto de contrariar o que dispõe a lei. Entendiam, ademais, que a admissão da cláusula resolutiva por falência se chocaria com a regra legal que determina que os contratos podem ser cumpridos após a decretação da falência se, como já visto acima, seu cumprimento reduzir ou evitar o aumento do passivo da massa falida ou for necessário à manutenção e preservação de seus ativos.

Essa corrente de pensamento ressaltava, ainda, que à falida não se permite eximir-se de suas obrigações contratuais pelo fato de ficar ao justo critério do administrador cumprir ou exonerar-se dos contratos bilaterais . A

\footnotetext{
${ }^{75}$ COELHO, Fábio Ulhoa. Comentários à nova Lei de Falências e de recuperação de empresas: Lei n. 11.101, de 9-2-2005. $2^{\text {a }}$ ed.. - São Paulo: Saraiva, 2005. p. 317.
} 
partir do momento em que opta o administrador pela manutenção do contrato, deve prosseguir cumprindo a sua parte da avença, sob pena de o outro contratante igualmente se desobrigar das obrigações contraídas em razão desse inadimplemento, como autoriza o artigo 476 do Código Civil ${ }^{76}$.

Diante dessa eventual divergência de entendimentos, nos filiamos à primeira corrente, totalmente majoritária nos dias de hoje, por entendermos que, ao pactuarem as partes sobre as conseqüências que a eventual quebra de uma delas trará para o vinculo contratual, acordando mutuamente que este vinculo se desconstituirá naquela hipótese, afastam, os contratantes, a aplicação das normas do direito falimentar. Entendemos que a prevalência desse entendimento garantirá uma maior segurança jurídica às relações contratuais, o que no âmbito do moderno direito empresarial deve ser preservado.

Com isso, temos que o contrato de cambio (em que houve adiantamento por parte do banco) que não esteja vencido quando da decretação da falência do cliente-exportador, não terá seu vencimento antecipado em razão dela. Assim é que, com base no parágrafo primeiro do art. 117 da Lei 11.101/05, deve o banco interpelar o administrador judicial, no prazo de até 90 dias, contado da assinatura do termo de sua nomeação, para que, dentro de 10 dias, declare se cumpre ou não o contrato.

Se o administrador responder negativamente ou simplesmente se omitir, opera-se a rescisão do contrato de pleno direito e o banco poderá, desde logo, tomar as medidas judiciais cabíveis, quais sejam, pedido de restituição do adiantamento e habilitação quirografária dos acessórios do contrato e despesas correlatas.

Ressalta-se, entretanto, que se o contrato de câmbio contiver cláusula determinando seu vencimento antecipado em caso de decretação de falência do devedor, entendemos que o banco pode ir diretamente às medidas judiciais cabíveis para reaver seu crédito (pedido de restituição e habilitação

\footnotetext{
76 "Art. 476 - Nos contratos bilaterais, nenhum dos contratantes, antes de cumprida a sua obrigação, pode exigir o implemento da do outro".
} 
quirografária), sem necessidade de interpelação do administrador judicial da massa falida.

Cabe lembrar que, concomitantemente às medidas judiciais acima referidas, podem ser executadas contra os avalistas as notas promissórias emitidas em favor do banco em representação e garantia da dívida oriunda da operação de câmbio, salvo se o contrato tiver sua execução continuada e a obrigação da sociedade falida ainda não estiver vencido.

\subsection{SUJEIÇÃO DO CRÉDITO ORIUNDO DE ACC AOS EFEITOS DA RECUPERAÇÃO JUDICIAL DO DEVEDOR-EXPORTADOR}

Visto o procedimento para a recuperação do crédito oriundo de contrato de câmbio quando da falência do exportador, passamos a nos deter na hipótese de recuperação judicial do cliente exportador que, através de um contrato de câmbio firmado com uma instituição financeira, tenha recebido um adiantamento sobre dito contrato dos reais equivalentes à quantia em moeda estrangeira que vendeu.

Pois bem, cumpre salientar, inicialmente, que, à luz do disposto na Nova Lei de Falências, em seu art. $49^{77}$, a recuperação judicial atinge, como regra, todos os credores existentes ao tempo da impetração do benefício.

$\mathrm{O}$ crédito decorrente de adiantamentos de contratos de câmbio (ACC), entretanto, por expressa previsão legal consubstanciada nos arts. 49, $\S 4^{\circ} \mathrm{c} / \mathrm{c} 86$, II, ambos da Lei no 11.101 , de 9.02.05, está excluído dos efeitos da recuperação judicial do devedor-exportador, senão vejamos:

Art. 49. Estão sujeitos à recuperação judicial todos os créditos existentes na data do pedido, ainda que não vencidos.

(... )

$\S 4^{\circ}$ Não se sujeitará aos efeitos da recuperação judicial a importância a que se refere o inciso II do art. 86 desta Lei.

\footnotetext{
${ }^{77}$ BRASIL. Lei $n$ 11.101, de 9 fev 2005. Regula a recuperação judicial, a extrajudicial e a falência do empresário e da sociedade empresária. Art. 49: "Estão sujeitos à recuperação judicial todos os créditos existentes na data do pedido, ainda que não vencidos".
} 
Art. 86. Proceder-se-á à restituição em dinheiro:

(...)

II - da importância entregue ao devedor, em moeda corrente nacional, decorrente de adiantamento a contrato de câmbio para exportação, na forma do art. 75 , §§ 3o e 4o, da Lei no 4.728, de 14 de julho de 1965 , desde que o prazo total da operação, inclusive eventuais prorrogações, não exceda o previsto nas normas específicas da autoridade competente. ${ }^{78}$

Como já visto acima, quis o legislador, como forma de fomentar as exportações no país, conferir a esses credores o direito de restituição e privilégio absoluto em relação aos demais credores sujeitos ao regime da recuperação judicial, ou seja:

os bancos que anteciparam recursos ao exportador em função do contrato de câmbio estão excluídos dos efeitos da recuperação judicial para que possam praticar juros menores (com spreads não impactados pelo risco associado à recuperação judicial), contribuindo a lei, desse modo, com a criação do ambiente propício à retomada do desenvolvimento econômico. ${ }^{79}$

Dessa forma, o crédito da instituição financeira credora por adiantamentos a exportação, está preservado da recuperação judicial, o que quer dizer, que não há hipótese de seu crédito ser alterado ou novado pelo plano de recuperação judicial contra sua vontade, mesmo que a alteração seja essencial à superação da crise do devedor.

Não há qualquer divergência doutrinária ou jurisprudencial sobre a exclusão dos créditos decorrentes de ACCs da recuperação judicial. Fábio Ulhoa Coelho lembra, de fato, que:

os bancos credores por adiantamento aos exportadores (ACC) não se sujeitam aos efeitos da recuperação judicial. (...) Esses credores excluídos dos efeitos da recuperação judicial não são minimamente atingidos pela medida e podem continuar exercendo seus direitos reais e contratuais nos termos da lei própria. ${ }^{80}$

No mesmo sentido, Paulo Fernando Campos Salles de Toledo, Professor de Direito Comercial da Faculdade de Direito do Largo de São Francisco e Desembargador aposentado do e. TJSP, ensina que:

\footnotetext{
${ }^{78}$ BRASIL. Lei n 11.101, de 9 fev 2005. Regula a recuperação judicial, a extrajudicial e a falência do empresário e da sociedade empresária. Art. 49.

${ }^{79}$ COELHO, Fábio Ulhoa. Comentários à nova Lei de Falências e de recuperação de empresas: Lei n. 11.101, de 9-2-2005. $2^{\text {a }}$ ed.. - São Paulo: Saraiva, 2005. p. 132.

${ }^{80}$ Ibid. p. 132.
} 
Por outro lado, também o adiantamento por contrato de câmbio 'não se sujeitará aos efeitos da recuperação judicial'. Desse modo, poderão as instituições financeiras credoras promover a cobrança, por meio de processo de execução, desses adiantamentos feitos a exportadores, por conta do valor de contrato de câmbio. A execução não se suspenderá pelo processamento da recuperação judicial pelo devedor. ${ }^{81}$

Dessa forma, por força do disposto no art. 49, parágrafo $4^{\circ}$ da Lei de Falência acima explicitado, o valor correspondente ao adiantamento efetuado em moeda corrente nacional, oriundo de contrato de câmbio para exportação, não está sujeito aos efeitos da recuperação judicial. Por tal razão, pode-se depreender que o valor do adiantamento de contrato de câmbio pode ser exigido em sede de execução ajuizada contra o devedor que esteja em recuperação judicial.

Vale lembrar que quanto aos valores relativos à diferença de taxa cambial e encargos devidos em razão do inadimplemento do contrato de câmbio (incluindo encargos moratórios, multas, IOF, dentre outros), podese dizer que os mesmos estão sujeitos aos efeitos da recuperação judicial, haja vista que a diferença de taxa cambial e os encargos não compõem o valor adiantado, sendo apenas acessórios ao mesmo. Diante disso, nos dispusemos a averiguar as possíveis conseqüências da cobrança da diferença de taxa cambial e dos demais encargos na ação de execução, juntamente com o valor adiantado.

Entendemos que, nesse caso, há risco de alegação por parte do embargante da ocorrência de excesso de execução, porquanto os valores referentes à diferença de taxa cambial e aos encargos não podem ser cobrados em sede em execução, tendo em vista que tais valores estão sujeitos aos efeitos da recuperação judicial, pelo fato de serem acessórios ao valor adiantado.

Cumpre esclarecer que o "excesso de execução" pode ser sempre fundamento dos embargos de devedor. De acordo com o disposto no art.

\footnotetext{
${ }^{81}$ SALLES DE TOLEDO, Paulo F. C.; ABRÃO, Carlos Henrique (coord). Comentários à Lei de Recuperação de Empresas e Falência. São Paulo: Saraiva, 2005. p. 21.
} 
739-A, parágrafo $5^{\circ}$ do $\mathrm{CPC}^{82}$, quando o excesso de execução for fundamento dos embargos de devedor, o embargante deverá declarar na petição dos embargos o valor que entende correto, apresentando memória de cálculo, sob pena de rejeição liminar dos embargos ou de não conhecimento do referido fundamento.

Caso o fundamento seja acolhido pelo juiz, o mesmo poderá condenar as partes (Banco e devedor) ao pagamento de honorários de sucumbência recíproca, na forma do disposto no art. 21 do $\mathrm{CPC}^{83}$. Ou seja, o Banco poderia ser condenado ao pagamento de honorários de sucumbência sobre o valor excedente à execução (diferença de taxa cambial e demais encargos).

Para melhor entendimento dos honorários de sucumbência, cumpre esclarecer que são os honorários advocatícios e as despesas realizadas pela parte vencedora. A regra geral que trata dos honorários de sucumbência encontra-se no art. 20 do $\mathrm{CPC}^{84}$. De acordo com o referido dispositivo

\footnotetext{
82 “Art. 739-A. Os embargos do executado não terão efeito suspensivo.

(...)

$5^{\mathrm{o}}$ Quando o excesso de execução for fundamento dos embargos, o embargante deverá declarar na petição inicial o valor que entende correto, apresentando memória do cálculo, sob pena de rejeição liminar dos embargos ou de não conhecimento desse fundamento".

83 "Art. 21. Se cada litigante for em parte vencedor e vencido, serão recíproca e proporcionalmente distribuídos e compensados entre eles os honorários e as despesas.

Parágrafo único. Se um litigante decair de parte mínima do pedido, o outro responderá, por inteiro, pelas despesas e honorários".

84 “Art. 20. A sentença condenará o vencido a pagar ao vencedor as despesas que antecipou e os honorários advocatícios. Esta verba honorária será devida, também, nos casos em que o advogado funcionar em causa própria.

$\S 1^{\circ} \mathrm{O}$ juiz, ao decidir qualquer incidente ou recurso, condenará nas despesas o vencido.

$\S 2^{\circ}$ As despesas abrangem não só as custas dos atos do processo, como também a indenização de viagem, diária de testemunha e remuneração do assistente técnico.

$\S 3^{\circ}$ Os honorários serão fixados entre o mínimo de dez por cento $(10 \%)$ e o máximo de vinte por cento $(20 \%)$ sobre o valor da condenação, atendidos:
}

a) o grau de zelo do profissional;

b) o lugar de prestação do serviço;

c) a natureza e importância da causa, o trabalho realizado pelo advogado e o tempo exigido para o seu serviço.

$\S 4^{\circ}$ Nas causas de pequeno valor e nas de valor inestimável, bem como naquelas em que não houver condenação ou for vencida a Fazenda Pública, os honorários serão fixados consoante apreciarão equitativa do juiz atendidas as normas das letras a a c do parágrafo anterior.

$\S 4^{\circ}$ Nas causas de pequeno valor, nas de valor inestimável, naquelas em que não houver condenação ou for vencida a Fazenda Pública, e nas execuções, embargadas ou não, os honorários serão fixados consoante apreciação eqüitativa do juiz, atendidas as normas das alíneas a, b e c do parágrafo anterior.

$\S 5^{\circ}$ Nas ações de indenização por ato ilícito contra pessoa, o valor da condenação será a soma das prestações vencidas com o capital necessário a produzir a renda correspondente às prestações 
legal, a sentença condenará o vencido a pagar ao vencedor as despesas que antecipou e os honorários advocatícios.

Cabe ressaltar que as despesas abrangem não só as custas dos atos do processo, como também a indenização de viagem, diária de testemunha e remuneração do assistente técnico. Quanto aos honorários advocatícios, estes são fixados entre o mínimo de $10 \%$ e o máximo de $20 \%$ sobre o valor da condenação, atendidos (i) o grau de zelo do profissional; (ii) o lugar de prestação do serviço; e (iii) a natureza e importância da causa, o trabalho realizado pelo advogado e o tempo exigido para o seu serviço.

Importante, destacar, ainda quanto a este tópico, que os direitos do credor quanto ao recebimento de seus créditos decorrentes de dívida assumida pela empresa em recuperação judicial não precluem durante o processo da recuperação judicial. Dessa forma, caso seja acolhido o fundamento de excesso de execução pelo juiz que julgará os embargos de devedor, quanto à cobrança pelo Banco da diferença de taxa cambial e demais encargos, poderá o Banco habilitar tais créditos de forma retardatária.

Nesse sentido, dispõe o art. 10, parágrafos $5^{\circ}$ e $6^{\circ}$ da Lei de Falência $^{85}$ ao afirmar ser sempre cabível ao credor habilitar seu crédito.

vincendas (art. 602), podendo estas ser pagas, também mensalmente, na forma do $\S 2^{0}$ do referido art. 602, inclusive em consignação na folha de pagamentos do devedor".

85 “Art. 10. Não observado o prazo estipulado no art. 7o, § 1o, desta Lei, as habilitações de crédito serão recebidas como retardatárias.

$\S 1$ o $\mathrm{Na}$ recuperação judicial, os titulares de créditos retardatários, excetuados os titulares de créditos derivados da relação de trabalho, não terão direito a voto nas deliberações da assembléiageral de credores.

$\S 20$ Aplica-se o disposto no $\S 1$ 1o deste artigo ao processo de falência, salvo se, na data da realização da assembléia-geral, já houver sido homologado o quadro-geral de credores contendo o crédito retardatário.

§ 3o Na falência, os créditos retardatários perderão o direito a rateios eventualmente realizados e ficarão sujeitos ao pagamento de custas, não se computando os acessórios compreendidos entre o término do prazo e a data do pedido de habilitação.

$\S 4 \mathrm{o}$ Na hipótese prevista no $\S 30$ deste artigo, o credor poderá requerer a reserva de valor para satisfação de seu crédito.

§ 5o As habilitações de crédito retardatárias, se apresentadas antes da homologação do quadrogeral de credores, serão recebidas como impugnação e processadas na forma dos arts. 13 a 15 desta Lei.

§ 6o Após a homologação do quadro-geral de credores, aqueles que não habilitaram seu crédito poderão, observado, no que couber, o procedimento ordinário previsto no Código de Processo Civil, requerer ao juízo da falência ou da recuperação judicial a retificação do quadro-geral para inclusão do respectivo crédito". 
Caso isso ocorra após o prazo de 15 dias, contados da publicação do edital da recuperação judicial (prazo legal previsto para habilitação), a habilitação de crédito será recebida como retardatária.

$\mathrm{Na}$ hipótese das habilitações de crédito retardatárias serem apresentadas antes da homologação do quadro-geral de credores, serão recebidas como impugnação e processadas normalmente. Por outro lado, se as habilitações de crédito forem apresentadas após a homologação do quadro-geral de credores, aqueles que não habilitaram seu crédito poderão, observado, no que couber, o procedimento ordinário previsto no CPC, requerer ao juízo recuperação judicial a retificação do quadro-geral para inclusão do respectivo crédito.

É importante observar que, nos termos do art. 10, parágrafo primeiro da Lei de Falência, o credor habilitado retardatariamente, na recuperação judicial, não terá direito a voto nas deliberações da assembléia-geral de credores, a menos que na data da assembléia seus créditos já tenham sido admitidos pela decisão judicial, nos termos do art. 39 da Lei de Falência ${ }^{86}$.

Ressalte-se, também, que os credores retardatários perderão a oportunidade de participar dos rateios realizados conforme o plano de recuperação judicial aprovado, antes da admissão de seus créditos na recuperação judicial, conforme previsão do parágrafo terceiro do mesmo art. 10.

No que diz respeito ao pagamento de custas, o credor retardatário fica sujeito ao pagamento das mesmas, uma vez que terá dado causa às despesas com a efetivação dos atos processuais da habilitação retardatária.

Adicionalmente, de acordo com o disposto no art. 10, parágrafo $4^{\circ}$ da Lei de Falência, conforme já explicitado, deve-se atentar para o fato de que é permitido ao credor retardatário pleitear a reserva do valor correspondente

\footnotetext{
86 “Art. 39. Terão direito a voto na assembléia-geral as pessoas arroladas no quadro-geral de credores ou, na sua falta, na relação de credores apresentada pelo administrador judicial na forma do art. $7 \mathrm{o}, \S 2 \mathrm{o}$, desta Lei, ou, ainda, na falta desta, na relação apresentada pelo próprio devedor nos termos dos arts. 51, incisos III e IV do caput, 99, inciso III do caput, ou 105, inciso II do caput, desta Lei, acrescidas, em qualquer caso, das que estejam habilitadas na data da realização da assembléia ou que tenham créditos admitidos ou alterados por decisão judicial, inclusive as que tenham obtido reserva de importâncias, observado o disposto nos §§ 1 o e 2 o do art. 10 desta Lei".
} 
ao seu crédito. Caso seja deferida a reserva, a empresa em recuperação judicial estará obrigada a providenciá-la, ainda que não conste do plano de recuperação previsão expressa de pagamento a tal credor.

Por fim, ressaltamos, que assim como nas outras hipóteses de execução analisadas acima, mesmo sendo deferida a recuperação judicial do cliente-exportador, pode a instituição financeira, em virtude da autonomia das obrigações corporificadas no contrato de câmbio e na eventual nota promissória a ele vinculada, (i) tentar reaver seus créditos quirografários (valores relativos à diferença de taxa e demais encargos) habilitando-os no âmbito da recuperação judicial; (ii) executar o cliente-exportador com base nos adiantamentos realizados; e (iii) executar os avalistas, solventes, das notas promissórias porventura emitidas em representação e garantia da dívida decorrente do contrato de câmbio. 


\section{CONCLUSÃO}

No curso do presente trabalho buscou-se, com base nas principais características do contrato de câmbio, notadamente sua natureza jurídica de compra e venda de divisas, examinar as consequiências jurídicas do inadimplemento do mesmo por parte do exportador, inclusive em decorrência de sua falência ou recuperação judicial, apontando-se, conseqüentemente, o caminho a ser seguido em Juízo pela instituição financeira quando da execução judicial do referido instrumento. Dedicouse especial atenção aos meios e trâmites que devem ser percorridos pelo banco credor para fins de ressarcimento de seus prejuízos e recuperação de seu crédito (eventual adiantamento concedido sobre o preço das divisas negociadas).

No que diz respeito à posição do credor do contrato de câmbio de exportação quando da falência ou recuperação judicial do exportador, procurou-se evidenciar o fím econômico a que visa o contrato de câmbio, que possui um interesse público intrínseco, para justificar o tratamento diverso recebido pelos bancos.

Ao facilitar o retorno à instituição financeira do valor adiantado ao exportador em decorrência do contrato de câmbio, a lei falimentar barateia o financiamento da exportação haja vista parte das taxas cobradas pelas instituições financeiras é pressionada pelos riscos associados à insolvência do devedor, estimulando, dessa forma, as exportações. A Lei não poderia, forçoso é reconhecer, dar qualquer estímulo sem, de algum modo, privilegiar a posição desse credor em particular. Logo, temos que, o privilégio concedido ao credor de ACC visa a garantir um bem maior, qual seja, o estímulo às exportações brasileiras.

Neste sentido, destaca-se o importante instituto do Pedido de Restituição, que garante às instituições financeiras o direito à restituição das quantias relativas a adiantamento de contrato de câmbio prioritariamente a quaisquer créditos da massa falida do cliente exportador, haja vista que tais 
valores representam dinheiro de terceiro em poder da pessoa jurídica do devedor ${ }^{87}$.

Além disso, é imprescindível destacar que a facilitação e barateamento do financiamento aos exportadores representam medida de interesse nacional. Ao estabelecer a lei a restituição das quantias adiantadas ao exportador falido com base num contrato de câmbio, definindo o crédito da instituição financeira como extraconcursal, atenua-se o risco associado à insolvência e, conseqüentemente, os juros cobrados nessa linha de financiamento, ajudando, em última instância, o enfrentamento do desafio nacional pela redução da dependência externa.

Cabe dizer ainda que o privilégio conferido aos bancos visa muito mais atender ao interesse nacional de estímulo às exportações que ao interesse privado das instituições financeiras relacionado à recuperação do seu crédito. É evidente que tais interesses se casam, não sendo minimamente possível atender-se a qualquer um deles desprezando o outro, mas o objetivo do legislador foi, inegavelmente, o de tutelar o fortalecimento da economia brasileira.

Por fim, é de se destacar que o adiantamento do contrato de câmbio é essencial para a sobrevivência das empresas exportadoras. Por meio desses contratos, tais empresas obtêm o necessário capital de giro para assumir os altos custos de exportação que apenas serão recompensados meses após, quando do pagamento pelos importadores das mercadorias. Não é por outro motivo que o legislador, como forma de fomentar as exportações no país, conferiu aos credores de ACC o referido direito de restituição e privilégio absoluto em relação aos demais credores sujeitos ao regime da recuperação judicial.

Assim, dada a importância dos ACCs para as exportações, o legislador reduziu os riscos desses créditos, conferindo-lhes privilégio e permitindo ainda que as empresas passassem a exportar em condições mais

\footnotetext{
${ }^{87}$ V. Item 3.1 e 3.2 do presente trabalho.
} 
favoráveis, sem recorrer aos meios convencionais de empréstimos oferecidos pelas instituições financeiras. 


\section{BIBLIOGRAFIA}

ASSIS, Araken de. Comentários do Código de Processo Civil. v. VI. Rio de Janeiro: Forense, 1999. 329 p.

BRASIL. Decreto-Lei n 7.661, de 21 jun 1945. Lei de Falências. . Lei $n$ 4.728, de 14 jul 1965. Disciplina o mercado de capitais e estabelece medidas para o seu desenvolvimento.

. Lei $n$ 5.869, de 11 jan 1973. Institui o Código de Processo Civil. . Lei n 10.406, de 10 jan 2002. Código Civil.

. Lei $n$ 11.101, de 9 fev 2005. Regula a recuperação judicial, a extrajudicial e a falência do empresário e da sociedade empresária.

CAVAlCANTI, Fernando Geraldo Mendes. Contrato de câmbio de exportação em juízo. Rio de Janeiro: Renovar, 1989. 242 p.

CINTRA, Antônio Carlos de Araújo; GRINOVER, Ada Pellegrini; DINAMARCO, Cândido Rangel. Teoria Geral do Processo. 21ª ed. Rio de Janeiro: Malheiros Editores; 2005. 368 p.

COELHO, Fábio Ulhoa. Comentários à nova Lei de Falências e de recuperação de empresas: (Lei $n$. 11.101, de 9-2-2005). 2a ed. São Paulo: Saraiva, 2005. 703 p.

. Curso de Direito Comercial. v. 2. $8^{\text {a }}$ ed. São Paulo: Saraiva, 2005. $514 \mathrm{p}$.

EIZIRIK, Nelson; GAAL, Ariádna B.; PARENTE, Flávia; HENRIQUES Marcus de Freitas. Mercado de Capitais - Regime Jurídico. Rio de Janeiro: Renovar, 2008. 624 p.

FORTUNA, Eduardo. Mercado Financeiro: produtos e serviços. $17^{\mathrm{a}}$ ed. Rio de Janeiro: Qualitymark, 2008. 833 p.

GOMES, Orlando. Contratos. 12a ed. Rio de Janeiro: Forense; 1987.592 p. LACERDA, J. C. Sampaio de. Manual de Direito Falimentar. $13^{\mathrm{a}}$ ed. Rio de Janeiro: Freitas Bastos, 1996. 161 p.

MONTEIRO, Washington de Barros. Curso de Direito Civil. Direito das Obrigações. v. 5. 17 a ed. São Paulo: Saraiva, 1981-1982. 424 p. 
NEVES, Daniel Amorim Assumpção. Reforma do CPC. v. 2. São Paulo: Revista dos Tribunais, 2007. 288 p.

PACHECO, José da Silva. Do contrato de câmbio como título executivo. In: Informativo Semanal 16/99, ADV - Advogacia Dinâmica. 246-247 p. PEREIRA, Caio Mário da Silva. Instituições de Direito Civil. v. III. $12^{\mathrm{a}}$ ed. Rio de Janeiro: Forense, 2006. 604 p.

REQUIÃO, Rubens. Aspectos modernos do Direito Comercial. v. 2. São Paulo: Saraiva, 1980. 358 p.

. Curso de Direito Falimentar. v. I. $11^{\mathrm{a}}$ ed. São Paulo: Saraiva, 1986. 247 p.

SALLES DE TOLEDO, Paulo F. C.; ABRÃO, Carlos Henrique. Comentários à Lei de Recuperação de Empresas e Falência. São Paulo: Saraiva, 2005. 837 p.

SALOMÃo NETO, Eduardo. Direito Bancário. São Paulo: Atlas, 2007. $615 \mathrm{p}$.

THEODORO JÚNIOR, Humberto. Curso de Direito Processual Civil. v. II. $42^{\mathrm{a}}$ ed. Rio de Janeiro: Forense, 2007. 241 p.

WALD, Arnoldo. Revista de Direito Bancário e do Mercado de Capitais. Ano 10. n.36. São Paulo: Revista dos Tribunais; 2007. 213 p.

WAMBIER, Luiz Rodrigues; ALMEIDA, Flávio Renato Correia de; TALAMINI, Eduardo. Curso Avançado de Processo Civil. v. II. São Paulo: Revista dos Tribunais, 1998. 145 p.

ZERBINI, Vitor Alberto. Câmbio e comércio exterior: princípio e prática. São Paulo: Resenha Universitária, 1975. 61 p. 